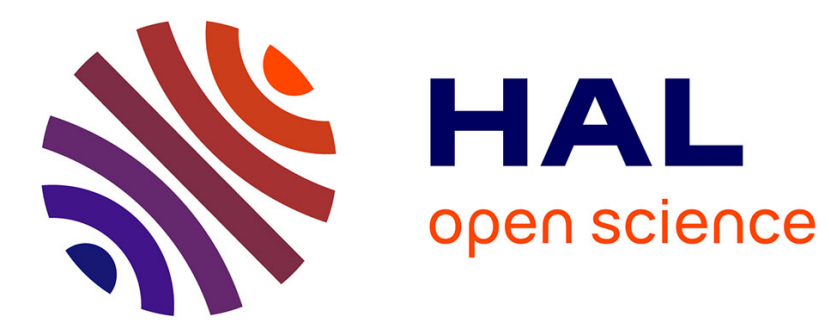

\title{
North-western Mediterranean sea-breeze circulation in a regional climate system model
}

\author{
Philippe Drobinski, Sophie Bastin, Thomas Arsouze, Karine Beranger, \\ Emmanouil Flaounas, Marc Stefanon
}

\section{- To cite this version:}

Philippe Drobinski, Sophie Bastin, Thomas Arsouze, Karine Beranger, Emmanouil Flaounas, et al.. North-western Mediterranean sea-breeze circulation in a regional climate system model. Climate Dynamics, 2018, 51 (3), pp.1077-1093. 10.1007/s00382-017-3595-z . insu-01500417

\section{HAL Id: insu-01500417 https://hal-insu.archives-ouvertes.fr/insu-01500417}

Submitted on 3 Apr 2017

HAL is a multi-disciplinary open access archive for the deposit and dissemination of scientific research documents, whether they are published or not. The documents may come from teaching and research institutions in France or abroad, or from public or private research centers.
L'archive ouverte pluridisciplinaire HAL, est destinée au dépôt et à la diffusion de documents scientifiques de niveau recherche, publiés ou non, émanant des établissements d'enseignement et de recherche français ou étrangers, des laboratoires publics ou privés. 


\title{
North-western Mediterranean sea-breeze circulation in a regional climate system model
}

\author{
Philippe Drobinski ${ }^{1}$ Sophie Bastin ${ }^{2} \cdot$ Thomas Arsouze $^{3} \cdot$ Karine Béranger $^{4}$. \\ Emmanouil Flaounas ${ }^{5}$ Marc Stéfanon ${ }^{6}$
}

Received: 31 July 2015 / Accepted: 19 February 2017

(c) The Author(s) 2017. This article is an open access publication

\begin{abstract}
In the Mediterranean basin, moisture transport can occur over large distance from remote regions by the synoptic circulation or more locally by sea breezes, driven by land-sea thermal contrast. Sea breezes play an important role in inland transport of moisture especially between late spring and early fall. In order to explicitly represent the two-way interactions at the atmosphere-ocean interface in the Mediterranean region and quantify the role of air-sea feedbacks on regional meteorology and climate, simulations at $20 \mathrm{~km}$ resolution performed with WRF regional climate model (RCM) and MORCE atmosphere-ocean
\end{abstract}

This paper is a contribution to the special issue on MedCORDEX, an international coordinated initiative dedicated to the multi-component regional climate modelling (atmosphere, ocean, land surface, river) of the Mediterranean under the umbrella of HyMeX, CORDEX, and Med-CLIVAR and coordinated by Samuel Somot, Paolo Ruti, Erika Coppola, Gianmaria Sannino, Bodo Ahrens, and Gabriel Jordà.

Philippe Drobinski

philippe.drobinski@1md.polytechnique.fr

1 LMD/IPSL, Ecole polytechnique, Université Paris-Saclay, Sorbonne Universités, UPMC Univ., Paris 06, CNRS, Palaiseau, France

2 LATMOS/IPSL, UVSQ, Université Paris-Saclay, Sorbonne Universités, UPMC, Univ., Paris 06, CNRS, Guyancourt, France

3 École Nationale Supérieure des Techniques Avancées/ ParisTech, Université Paris-Saclay, Palaiseau, France

4 Laboratoire d'études des Transferts en Hydrologie et Environnement, CNRS, IRD, Grenoble INP and Université Joseph Fourier, St-Martin d'Héres, France

5 National Observatory of Athens, Athens, Greece

6 LSCE/IPSL, CEA and UVSQ, Université Paris-Saclay, CNRS, Gif sur Yvette, France regional climate model (AORCM) coupling WRF and NEMO-MED12 in the frame of HyMeX/MED-CORDEX are compared. One result of this study is that these simulations reproduce remarkably well the intensity, direction and inland penetration of the sea breeze and even the existence of the shallow sea breeze despite the overestimate of temperature over land in both simulations. The coupled simulation provides a more realistic representation of the evolution of the SST field at fine scale than the atmosphereonly one. Temperature and moisture anomalies are created in direct response to the SST anomaly and are advected by the sea breeze over land. However, the SST anomalies are not of sufficient magnitude to affect the large-scale seabreeze circulation. The temperature anomalies are quickly damped by strong surface heating over land, whereas the water vapor mixing ratio anomalies are transported further inland. The inland limit of significance is imposed by the vertical dilution in a deeper continental boundary-layer.

Keywords Air/sea interactions $\cdot$ Breeze $\cdot$ Mistral · MORCE regional climate system model $\cdot$ HyMeX $\cdot$ MEDCORDEX $\cdot$ ESCOMPTE

\section{Introduction}

The Mediterranean basin has quite a unique character that results from both physiographic and climatic conditions and historical and societal developments. Located between the midlatitude storm rainband and the Sahara Desert, the Mediterranean region experiences a profound seasonal hydrological cycle, with wet-cold winters and dry-warm summers (Peixoto et al. 1982) and a large variability at mesoscale. Indeed, the complex geography of the region, which features a nearly enclosed sea with high sea surface 
temperature (SST) during summer and fall, surrounded by very urbanized littorals and mountains (Fig. 1), plays a crucial role in steering airflow. The morphological complexity of the basin leads to the formation of intense weather phenomena, such as intense cyclogenesis (e.g. Alpert et al. 1995; Trigo et al. 1999), topographically-induced strong winds like Mistral (e.g. Drobinski et al. 2005; Guénard et al. 2005, 2006; Corsmeier et al. 2005) and Tramontane (e.g. Drobinski et al. 2001), which are companion winds blowing south from the French Mediterranean coast to the African coasts (Salameh et al. 2009). The Mediterranean Sea acts as a major source of atmospheric moisture for the atmosphere in the region which controls offshore (Luca et al. 2014; Lebeaupin-Brossier et al. 2015) and onshore precipitation (e.g. Lebeaupin et al. 2006; Lebeaupin Brossier et al. 2008, 2009; Lebeaupin-Brossier et al. 2013; Berthou et al. 2014, 2015, 2016).

In the Mediterranean region, sunny weather occurs over a rather long period of the year, from spring to fall. During this period, surface heating produces a significant thermal difference between land and sea. During daytime (nighttime), land temperature exceeds (is lower than) the sea surface temperature. Such differential heating produces breeze systems which can extend over a horizontal range of 100-150 km inland (Drobinski et al. 2006) and play an important role in inland transport of moisture (Bastin et al. 2005a, 2007). The horizontal extent of the breeze circulation is expected to be even larger in the Southern shore of the Mediterranean region as it scales as the Rossby deformation radius, which is inversely proportional to the

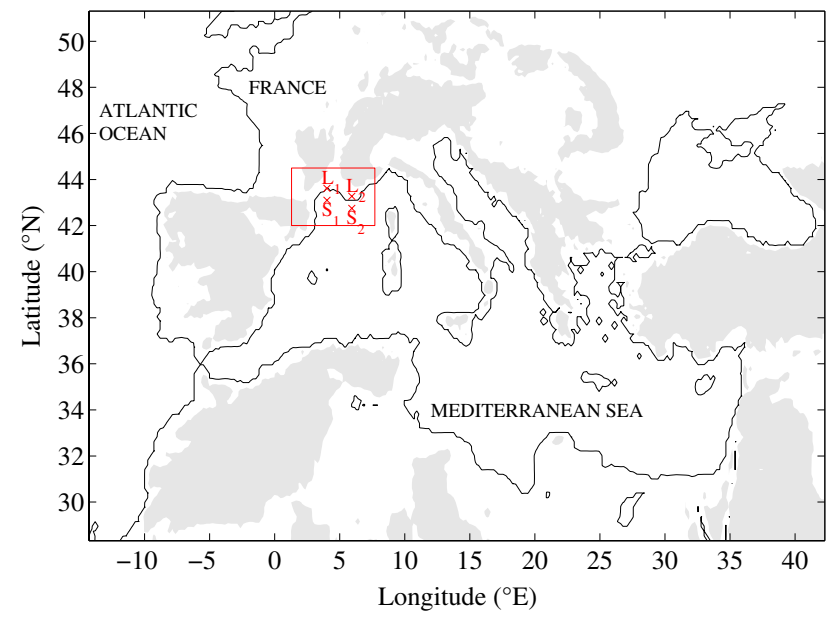

Fig. 1 Simulation domain of the HyMeX/MED-CORDEX regional climate simulations with the shaded area indicating a topography higher than $500 \mathrm{~m}$. The rectangle indicates the region of interest for this study. Locations " $\mathrm{S}_{1}$ ", " $\mathrm{S}_{2}$ ", " $\mathrm{L}_{1}$ ", " $\mathrm{L}_{2}$ " correspond to location points at which time series of oceanic and atmospheric variables will be displayed in the present study. Subscripts "1" and " 2 " will be identified as the "Mistral" and "Marseille" areas, respectively. Acronyms "S" and "L" stand for "Sea" and "Land", respectively
Coriolis parameter (Rotunno 1983; Dalu and Pielke 1989; Drobinski and Dubos 2009; Drobinski et al. 2011). The inland penetration which controls inland moisture advection and often determines the band where convection is triggered during warm seasons, can be modulated by interaction with mountain slopes (Kusuda and Alpert 1983; Bastin and Drobinski 2005), channeling in local valleys (Bastin et al. 2005a, b) or by synoptic wind (Estoque 1962; Arritt 1993), and particularly by Mistral (Bastin et al. 2006) or by major urban areas (Lemonsu et al. 2006).

Breeze phenomenon has never been investigated in global climate models (GCMs), since they have generally been used with too coarse horizontal grid resolution to explicitly resolve breeze circulation (i.e. $>100 \mathrm{~km}$ ). An improved knowledge of the Mediterranean hydrological cycle and its variability is needed which requires a better understanding of the mesoscale atmospheric flows like sea-breezes, which transport moisture over fairly large distances. It could yield important socioeconomic benefits with respect to regional projection of global change since the largest Mediterranean cities are located near the shore.

In the context of the Hydrological cycle in the Mediterranean Experiment (HyMeX; Drobinski et al. 2014) and the Coordinated Regional Downscaling Experiment (MED-CORDEX; Ruti et al. 2015), 10-20-km resolution simulations covering the full ERA-interim reanalysis period (1989-2008) have been performed with a number of regional climate models (RCMs) and sometimes also with atmosphere-ocean regional climate models (AORCMs). Such simulations have shown their ability to simulate coastal breezes. Indeed, Stéfanon et al. (2014) have shown the role of sea-breeze in attenuating summer heatwaves over the Mediterranean coast. However no thorough analysis has been undertaken on the breeze dynamics itself. The objective of this study is to take advantage of companion simulations used in atmosphere-only (RCMs) and in oceanatmosphere coupled (AORCM) modes to address the following question: How SST diurnal cycle simulated with AORCM modulates the main characteristics of the seabreeze (intensity, inland extent, vertical extent) with respect to RCM and how it modifies inland moisture? The study focuses on the North-Western Mediterranean because the strong regional winds like Mistral and Tramontane modulate the sea-surface temperature in the Gulf of Lions over time scale ranging between $1 \mathrm{~h}$ and few days (Lebeaupin Brossier and Drobinski 2009) which in turn affects the overlying atmospheric circulation (Fig. 1). A second reason is the availability of a large measurement dataset collected in the frame of the ESCOMPTE projet in 2001 (Cros et al. 2004; Mestayer et al. 2005) and available for model evaluation.

After the introduction in Sect. 1, the ESCOMPTE data subset used in the study, the numerical experiment 
set-up as well as the sea breeze cases are described in Sect. 2. Section 3 describes the sea surface temperature pattern and variability in the two simulations and analyzes the sensitivity of the simulations to the atmosphere/ocean coupling. Section 4 discusses the atmospheric response to SST differences induced by atmosphere/ocean coupled processes. Section 5 generalizes the results to the whole ESCOMPTE data set. Section 6 concludes this study and points out some open research questions needing further investigations.

\section{Data}

\subsection{Measurements}

The study focuses on the French Mediterranean coast (see zoom in Fig. 1). Indeed, in 2001, the ESCOMPTE projet (Cros et al. 2004; Mestayer et al. 2005), was conducted in June and July to improve the understanding and forecast of the main flow systems (sea-breeze and valley flow) and their role in the transport of moisture and pollutants in Southern France (region shown in the zoom of Fig. 1 where the large city of Marseille and its industrialized suburbs of Fos-Berre are major sources of pollutants). Two major flow regimes alternate during summertime in this region, the Mistral and Tramontane northerly-northwesterly winds and the sea breeze induced by the sea land temperature contrast which advects moisture and pollutants as far as $100 \mathrm{~km}$ inland thus affecting the inhabitants leaving in the countryside (e.g. Bastin et al. 2007; Drobinski et al. 2007).

A large number of data were collected (meteorological data from surface weather stations, radiosondes and constant volume balloons, wind profiles from lidar, radar and sodar profilers,...; see Cros et al. 2004 for more details) and meso-scale numerical simulations performed. They allowed the analysis of the mesoscale transport and dilution by the sea-breeze, of the impact of the topography (Bastin et al. 2005a, b; Bastin and Drobinski 2005) and major urban areas (Lemonsu et al. 2006) on the sea-breeze circulation. They also allowed the analysis of the contribution of the sea-breeze to the regional transport of humidity (Bastin et al. 2005a, 2007) and pollutants (Puygrenier et al. 2005; Menut et al. 2005) and the evaluation of existing sea-breeze scaling laws with the large body of observations collected during the campaign (Drobinski et al. 2006). A review of the main results from this campaign can be found in Drobinski et al. (2007). Such literature enables a critical evaluation of the HyMeX/MED-CORDEX simulations described hereafter.

\subsection{Models and simulations}

In order to explicitly represent the two-way interactions at the atmosphere-ocean interface in the Mediterranean region and quantify the role of air-sea feedbacks on regional meteorology and climate, Drobinski et al. (2012) developed an AORCM by coupling WRF RCM and NEMO-MED12 ocean model, and hereafter referred as MORCE (model of the regional coupled Earth system). It was developed by the Institut Pierre Simon Laplace (IPSL) in collaboration with Ecole Nationale des Techniques Avancées-ParisTech (ENSTA-ParisTech), Mediterranean Institute of Oceanography (MIO) and Centre Européen de Recherche et de Formation Avancée en Calcul Scientifique (CERFACS). This platform has been developed for process and regional climate system studies, especially in vulnerable regions. The configuration used for the HyMeX/MED-CORDEX simulations (physical parameterizations, initial and boundary conditions) are detailed below.

\subsubsection{The atmospheric and land-surface modules}

The atmospheric model is the Weather Research and Forecasting (WRF) model of the National Center for Atmospheric Research (NCAR) (Skamarock et al. 2008). The domain covers the Mediterranean basin with a horizontal resolution of $20 \mathrm{~km}$ (Fig. 1). It has 28 sigma-levels in the vertical. Initial and lateral conditions are taken from the European Center for Medium-range Weather Forecast (ECMWF) ERA-interim reanalysis (Dee et al. 2011) provided every $6 \mathrm{~h}$ with a $0.75^{\circ}$ resolution. Moreover, to avoid unrealistic departure from the driving fields, indiscriminate nudging is applied with a coefficient of $5 \times 10^{-5} \mathrm{~s}^{-1}$ for temperature, humidity and velocity components above the planetary boundary layer (Salameh et al. 2010; Omrani et al. 2013, 2015). A complete set of physics parameterizations is used with the WRF Single-Moment 5-class microphysical scheme (Hong et al. 2004), the new Kain-Fritsch convection scheme (Kain 2004), the Yonsei University (YSU) planetary boundary layer (PBL) scheme (Noh et al. 2003) and a parameterization based on the similarity theory (Monin and Obukhov 1954) for the turbulent fluxes. The radiative scheme is based on the Rapid Radiative Transfer Model (RRTM) (Mlawer et al. 1997) and the Dudhia (1989) parameterization for the longwave and shortwave radiation, respectively. For the land surface, the Rapid Update Cycle (RUC) land-surface model is used (Smirnova et al. 1997).

\subsubsection{The oceanic module}

The numerical code for the ocean is NEMO (Madec 2008), and is used in a regional Mediterranean configuration with 
a $1 \% / 12^{\circ}$ horizontal resolution (Lebeaupin-Brossier et al. 2011, 2012a, b). In the vertical, 50 unevenly spaced Z-levels are used. The vertical level thickness is $1 \mathrm{~m}$ in surface and nearly $4 \mathrm{~m}$ at $30 \mathrm{~m}$ depth. This eddy resolving model is referred as MED12 hereafter. The initial conditions for 3D potential temperature and salinity fields are provided by the MODB4 climatology (Brankart and Brasseur 1998) except in the Atlantic zone where the Levitus et al. 2005 climatology is applied. The water exchanges with the Atlantic Ocean are parameterized with a $3 \mathrm{D}$ relaxation to this climatology between $11^{\circ} \mathrm{W}$ and $6^{\circ} \mathrm{W}$. The runoffs and the Black Sea water input are prescribed from a climatology as precipitation (Beuvier et al. 2010). The vertical diffusion is performed by the standard turbulent kinetic energy model of NEMO and in case of instabilities a higher diffusivity coefficient of $10 \mathrm{~m}^{2} \mathrm{~s}^{-1}$ is used. The coupling consists in sea surface temperature (SST) and heat (solar and non-solar), water and momentum fluxes exchanges between the two models. The 3-hourly exchanges frequency and the fields interpolation are managed via the OASIS coupler (Valcke 2006).

\subsubsection{Simulations}

The simulations performed with WRF RCM and MORCE AORCM, cover the ERA-interim period between 1 January 1989 and 31 December 2012 and the simulation domain is shown in Fig. 1. Two simulations are hereafter examined:

- The downscaled ERA-interim reanalyses (1989-2008) by WRF RCM is named CTL hereafter and has been evaluated in-depth over the land surrounding the Mediterranean Sea (Claud et al. 2012; Flaounas et al. 2013; Stéfanon et al. 2014). The CTL simulations is forced by the ERA-interim SST at its lower boundary over the Mediterranean Sea.

- The downscaled ERA-interim reanalyses (1989-2008) by MORCE AORCM is named CPL and has been evaluated in-depth for precipitation, evaporation and wind speed over the Mediterranean Sea (Claud et al. 2012; Lebeaupin-Brossier et al. 2015). The CPL simulations is forced by the NEMO-MED12 SST at its lower boundary over the Mediterranean Sea.

At this point, it is important to stress that other RCM and AORCM simulations have been performed in the frame of HyMeX/MED-CORDEX program. However, a multimodel approach is not possible here as the numerical setups are much too different between the various simulations for a straightforward comparison. Indeed all the other AORCM simulations but one are not nudged (Drobinski et al. 2016). In nudged CTL and CPL simulations, the same model and hence the same physics are used so the effect of SST bias and air-sea feedbacks is isolated without any interference with other sources of error and uncertainty propagation, all other things being equal. Also, by constraining the large-scale field, the nudged simulations being from RCM and AORCM, have the spatial and temporal variability which allow a point to point, instant to instant comparison between the simulations. Finally, the only other nudged simulation is that performed by CNRM with a horizontal resolution of $50 \mathrm{~km}$ which considerably limits the simulation of the breeze. Their "CTL" simulation uses a monthly averaged ERA-interim SST field (instead of 3-hourly in the MORCE plateform), and their "CPL" simulation uses a daily time step coupling (instead of 3-hourly in the MORCE plateform). For these reasons, this sensitvity study only uses one single model.

\subsection{Brief description of the sea breeze cases}

In this article, we focus on the northwestern Mediterranean area between 21 and 26 June 2001 (see zoom in Fig. 1). This period corresponds to the second intensive observation period (IOP) of the ESCOMPTE campaign, which has been the most investigated period of the ESCOMPTE campaign as it basically covers all breeze situations that occur in this region. This period, referred as IOP2, has been split into two contiguous parts since meteorological conditions changed significantly on 23 June at 1700 UTC. The first period, hereafter called P1 (21-23 June) corresponds to the end of a Mistral situation with a moderate northwesterly to westerly wind, clear skies, hot temperature $\left(>30^{\circ} \mathrm{C}\right)$. The sea-breeze breaks through during the day but penetrates inland over a short distance $(50 \mathrm{~km})$ due to the frontal convergence with the Mistral from the north (Bastin et al. 2006; Drobinski et al. 2006). The second period, hereafter called P2 (24-26 June) best characterizes the most usual sea-breeze circulation configuration. During these three windless days, temperatures were hot $\left(>34{ }^{\circ} \mathrm{C}\right)$ and the sea-breeze penetrated over a horizontal distance reaching 100-150 km (Bastin et al. 2005a, b; Drobinski et al. 2006).

The surface flow pattern from the CTL and CPL simulations and from surface weather stations measurements is shown in Fig. 2 which displays the surface temperature (at 2-m height) and wind fields (at 10-m height) averaged over the P1 and P2 periods at 1800 UTC. Indeed, Bastin et al. (2005a, b), Bastin and Drobinski (2006) and Drobinski et al. (2006) show that in this area, the maximum inland penetration of the sea breeze is often found around 1600-1800 UTC, which coincides with the maximum of the diurnal temperature cycle (note that the local solar time which is a relevant time coordinate for breeze studies corresponds to universal time coordinate (UTC) +20 min; because of this small difference, we use the UTC time unit). The sea breeze front location corresponds to 

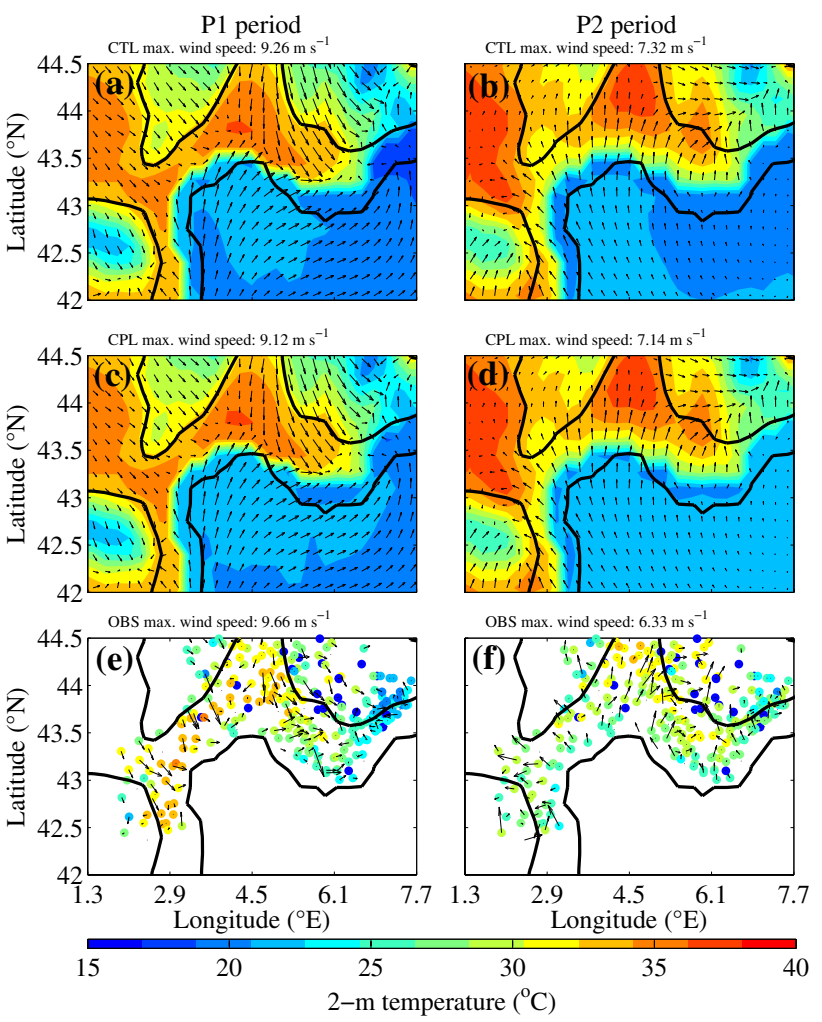

Fig. 2 2-m temperature (color) and 10-m wind (arrows) field averaged over the P1 period (21-23 June 2001) (left column; a, c, e) and the P2 period (24-26 June 2001) (right column; b, d, f) at 1800 UTC from CTL (upper row, $\mathbf{a}, \mathbf{b}$ ) and CPL (middle row, $\mathbf{c}, \mathbf{d}$ ) simulations, and from the Météo-France surface weather stations measurements (lower row, e, f). The thick lines indicate the coastline and the 500-m height topography

the location of the temperature maximum or/and (when it exists) the area where the wind reverses from the south (sea breeze flow) to the north. Figure 2 reveals differences in the surface temperature and wind field patterns between the CTL and CPL simulations, and between the simulations and the measurements. These differences will be discussed in the next sections.

During the P1 period (Fig. 2a, c, e), the sea breeze blows in the Marseille area (see point L2 in Fig. 1) where it takes a westerly direction because it combines with the Mistral. The simulations shows a 2-m temperature maximum in the Rhône valley at around $43.8^{\circ} \mathrm{N}$ where the sea breeze and the Mistral collide. This corresponds to an inland penetration of about $50 \mathrm{~km}$ in the Rhône valley, in good agreement with measurements of surface temperature and wind fields (Fig. 2; see also Table 2 in Drobinski et al. 2006), despite the large positive bias of the simulated temperature (about $+3{ }^{\circ} \mathrm{C}$ maximum) and a weak negative wind bias $(-0.4 \mathrm{~m}$ $\mathrm{s}^{-1}$ ) (Fig. 2). The Mistral is easily discernable with wind speed up to about $9 \mathrm{~m} \mathrm{~s}^{-1}$ and a pronounced northerly to northwesterly direction. The very small penetration of the

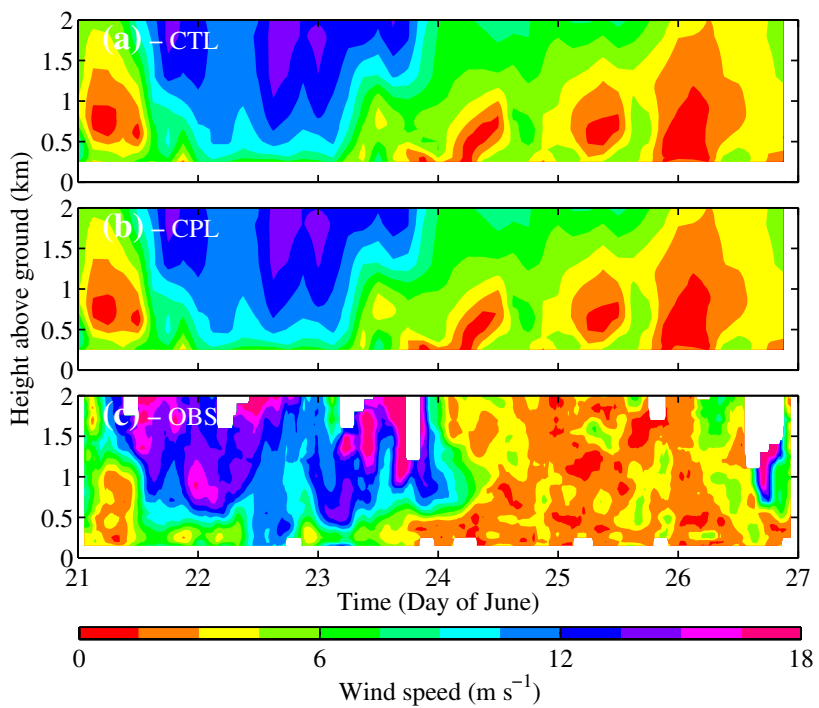

Fig. 3 Time-vs-height plots of wind speed in the "Marseille" area at location $\mathrm{L}_{2}$ (Fig. 1) from the CTL (a), CPL (b) simulations, and from UHF radar wind profiler (c) between 21 and 26 June 2001

sea breeze front is due to the offshore Mistral wind which inhibits the inland progress of the sea breeze (Bastin et al. 2006) and affects moisture transport (Bastin et al. 2007). During the P2 period, the surface wind and temperature fields clearly show the sea breeze establishment and the front location in a large region in the Rhône valley (between 44.0 and $44.5^{\circ} \mathrm{N}$ ) where there is no temperature gradient (Fig. 2b, d). The sea breeze front thus penetrates inland over a horizontal range of about $100-150 \mathrm{~km}$ in the Rhône valley which is also in agreement with the measurements (Fig. 2; see also Table 2 in Drobinski et al. 2006) and scaling laws which predict the typical horizontal extent to be of the order of the Rossby deformation radius $z_{i} N / f \sim 100$ $\mathrm{km}$ (with $z_{i} \sim 1 \mathrm{~km}$ the atmospheric boundary layer depth, $N \sim 10^{-2} \mathrm{~s}^{-1}$ the Brunt-Väisälä frequency and $f \sim 10^{-4} \mathrm{~s}^{-1}$ the Coriolis parameter at about $45^{\circ}$ latitude; see Rotunno 1983; Dalu and Pielke 1989; Drobinski and Dubos 2009; Drobinski et al. 2011). However, both the CTL and CPL simulations still overestimate significantly the onshore surface air temperature by nearly $+5^{\circ} \mathrm{C}$ (Fig. 2).

The time variability of the wind speed as a function of height is analyzed over land in the "Marseille" area (location $\mathrm{L}_{2}$ in Fig. 1) in Figs. 3 and 4 which respectively display the vertical profiles of the wind speed and direction from the CTL and CPL simulations and from a UHF radar wind profiler. Figures 3 and 4 clearly show the differences and the transition between the P1 and P2 periods. During the P1 period (21-23 June), the wind direction is north-northwesterly from the ground up to 2 $\mathrm{km}$ between 0000 and 1200 UTC. In this layer, the wind speed ranges from $5 \mathrm{~m} \mathrm{~s}^{-1}$ near the ground and can reach 


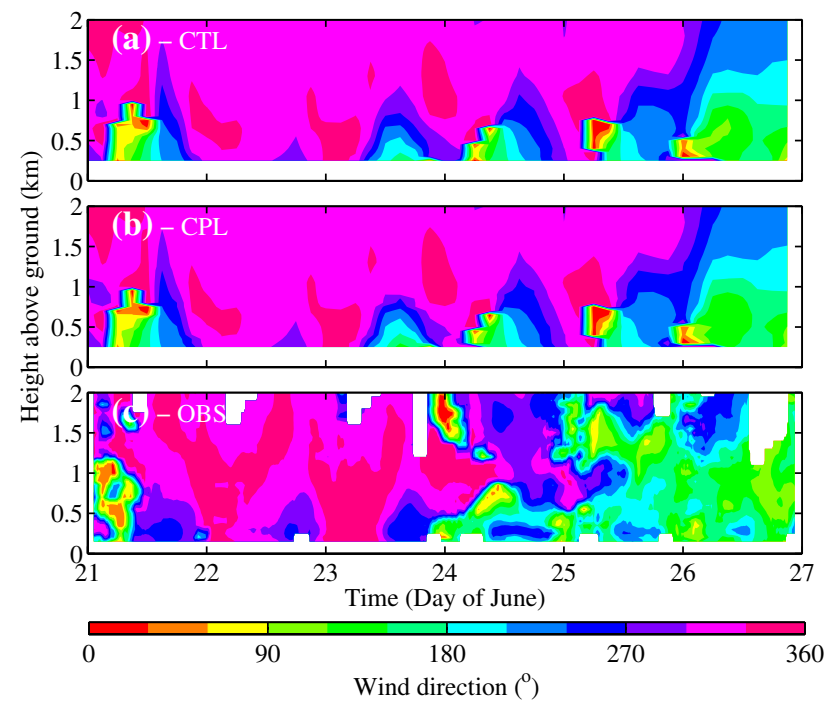

Fig. 4 Similar as Fig. 3 for wind direction

$12-15 \mathrm{~m} \mathrm{~s}^{-1}$ at $1-\mathrm{km}$ height and above. These simulations in good agreement with observations provide evidence that the whole layer between the surface and $2 \mathrm{~km}$ is affected by the Mistral, which intensity is weaker near the surface because of the friction. During the afternoon, two different layers are apparent. In a layer between the surface and about $600 \mathrm{~m}$ above ground, the wind direction is westerly-southwesterly, associated with wind speeds of about $5-8 \mathrm{~m} \mathrm{~s}^{-1}$. In a second layer between $600 \mathrm{~m}$ and $2 \mathrm{~km}$, the wind direction is again north-northwesterly, associated with an intensity of $7-12 \mathrm{~m} \mathrm{~s}^{-1}$. The existence of these two layers indicates the onset of the sea breeze in the afternoon (i.e., at about 1100 UTC on 21 June, at about 1500 UTC on 22 June, and at about 1300 UTC on 23 June) near the coastline that lifts the Mistral up to 700 or $800 \mathrm{~m}$. The low-level wind direction shift in the afternoon is present but less marked in the CTL and CPL simulations, which can in part be attributed to the too coarse vertical resolutions of the models. However, the wind speed variability is much more accurately simulated even though it is slightly underestimated in the simulations (about $-3 \mathrm{~m} \mathrm{~s}^{-1}$ around $1.5 \mathrm{~km}$ height). The weakness of the Mistral during this period allows the sea breeze to break through near the coastline where the temperature gradient between land and sea is maximum (Fig. 2). Thus, during the P1 period, the Mistral that blows near the surface during nighttime is not strong enough to inhibit the sea breeze (Arritt 1993; Bastin et al. 2006) and is replaced by a sea-breeze flow near the surface during the afternoon.

The transition between the $\mathrm{P} 1$ and $\mathrm{P} 2$ periods occurs during the afternoon of 23 June, when the Mistral weakens. During the P2 period, the diurnal cycle is not as well marked as during the $\mathrm{P} 1$ period in the observations because of the instrumental noise. The wind systems alternate between nocturnal katabatic flow combined with land breeze and diurnal anabatic flow combined with seabreeze which typically blow between $2 \mathrm{~m} \mathrm{~s}^{-1}$ at night and $4 \mathrm{~m} \mathrm{~s}^{-1}$ during daytime (Bastin and Drobinski 2005). Such values are consistently with scaling laws (Walsh 1974; Rotunno 1983; Niino 1987; Steyn 1998; Dalu and Pielke 1989; Steyn 2003; Drobinski and Dubos 2009; Drobinski et al. 2011). The typical $2 \mathrm{~m} \mathrm{~s}^{-1}$ diurnal amplitude is more difficult to capture in the observations than in the simulations which simulate a much clearer diurnal cycle with typical nighttime wind speed of $1-2 \mathrm{~m} \mathrm{~s}^{-1}$ and daytime of $4-5 \mathrm{~m} \mathrm{~s}^{-1}$. In the UHF radar observations the wind speed is quasi homogeneous with height. It is also the case in the simulation during daytime, whereas during nighttime, it increases from $1-2 \mathrm{~m} \mathrm{~s}^{-1}$ in the first kilometer (sea-breeze depth) to $4-5 \mathrm{~m} \mathrm{~s}^{-1}$ above. The wind direction also shows the existence of a diurnal cycle near the surface within several layers: up to about $300-400 \mathrm{~m}$, the wind alternates between westerly during daytime and easterly during nighttime, perpendicularly to the actual coastline. It blows up to about $1 \mathrm{~km}$ (sea-breeze depth) from south-westerly during daytime to north-easterly during nighttime and then veers to north-westerly above. The simulations also display a marked diurnal cycle but because of the "coarser" topography representation, the wind direction shifts between north-westerly during nighttime and south-easterly during daytime up to about $300-400 \mathrm{~m}$, perpendicularly to the model coastline. It then shifts between southerly during daytime to northerly during nighttime. As in the observations, the wind direction also veers to north-westerly above $1 \mathrm{~km}$.

The vertical variation of the wind direction corresponds to the co-existence of a shallow sea breeze which blows from the surface up to about $400 \mathrm{~m}$ below a deep seabreeze which blows above up to about $1 \mathrm{~km}$ (Bastin and Drobinski 2006; Lemonsu et al. 2006). Similarly to what Banta (1995) showed experimentally, two sea breezes do occur on two different depths and timescales: (1) a localscale temperature contrast close to the shoreline, which has a pattern correlated to the coastline shape, drives a shallow sea breeze blowing perpendicularly to the local coastline; (2) a larger-scale temperature contrast drives a deeper sea breeze blowing from the south (the isotherms have a predominant east-west orientation) that develops later in the day. On the contrary to Banta (1995) who observed that, by late afternoon, the shallow sea breeze blended into the deeper sea-breeze layer and was no longer evident, Bastin and Drobinski (2006) found that the shallow sea breeze persists all day long since the directions of the shallow and deep sea breezes are distinct in this region of complex coast 
shape. Because of the background synoptic wind which varies during the $\mathrm{P} 2$ period, the deep sea breeze direction also evolves. On 24 June, the synoptic situation induces a north-westerly flow in this second layer. On 25 June, during the day, the wind has a southerly direction, which is not well captured by the simulation above $1.5 \mathrm{~km}$. During the night and in the morning, this deep sea breeze does not exist and a westerly flow blows. On 26 June, the synoptic wind blows from the east. It has been shown that, on 26 June the low-level air mass, up to $2 \mathrm{~km}$ above ground, skirts the Mediterranean coast over land from the east-southeast (Lemonsu et al. 2006).

\section{SST analysis in the CTL and CPL regional climate simulations}

The sea-breeze circulation is primarily driven by a thermal contrast between land and sea, which is thus over the sea, in part controlled by the SST. In this section, we thus investigate the impact on the SST field of air/sea feedbacks in the CPL simulation and compare it to that from the CTL simulations and the observations.

\subsection{Spatial pattern of the SST fields}

Figure 5 shows the SST field averaged over the P1 and P2 periods from the CTL and CPL simulations and from the observations. More precisely, the SST observations are SST products optimally interpolated which have been produced in near-real time from direct assimilation in MFSTEP large scale model (OPA-MED16) of the AVHRR Pathfinder SST from the NASA/NOAA satellites. Original satellite data are available daily with a $4 \mathrm{~km}$ resolution. The optimally interpolated SST product finally covers the Mediterranean basin at $1 \% / 16^{\circ}$ resolution, dating back to 1985 , and accurately represents the Mediterranean SST when compared to in-situ measurements on board buoys, drifters or voluntary observing ships, and to ARGO profilers. The satellite data, the optimal interpolation scheme and the validation of the MFSTEP optimally interpolated SST product are fully described in Marullo et al. (2007). For the P1 period, Fig. 5 shows a cool SST plume visible at the exist of the Rhône valley and directly linked to the weak Mistral blowing between 21 and 23 June 2001 (Fig. 2a-c). It is present in the CTL and CPL simulations and in the observations but the fine scale structure is more accurately reproduced in the CPL simulation (Fig. 5b, c). Indeed, the Mistral, channeled in the Rhône valley, becomes a narrow streak jet over the Mediterranean Sea. The SST is directly modulated by the wind which enhances significantly the energy loss by the sea and the SST pattern is highly correlated with the wind pattern above (e.g. Lebeaupin Brossier and Drobinski
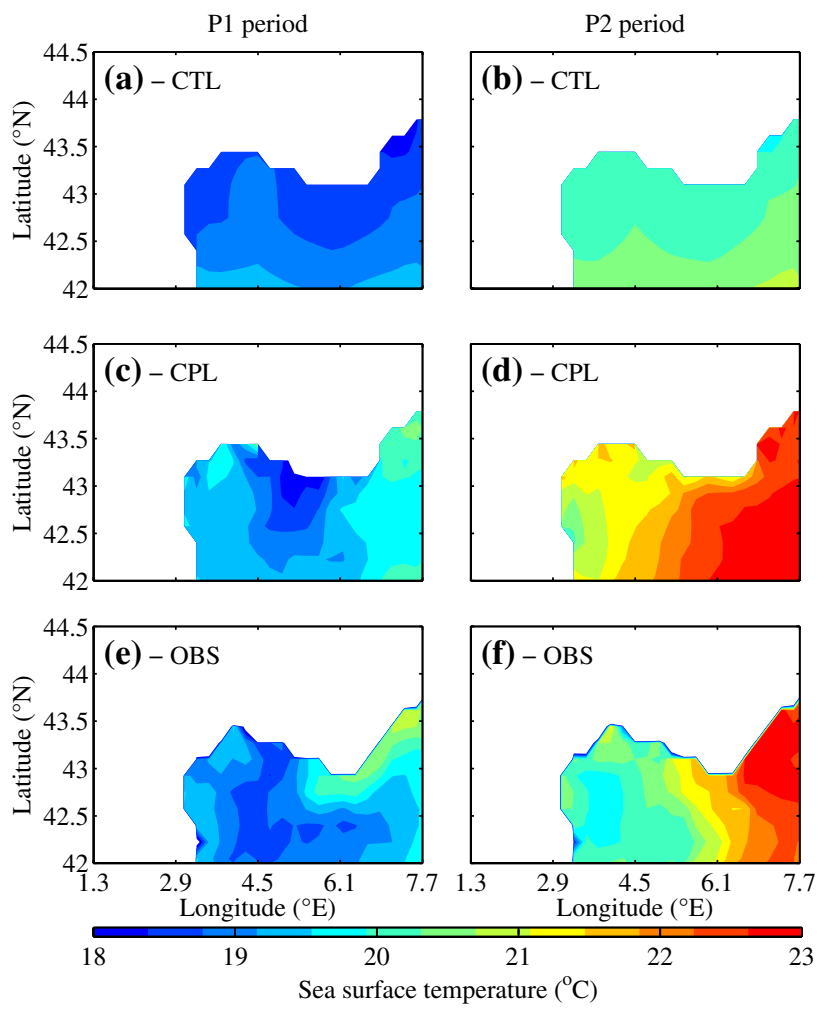

Fig. 5 SST field averaged over the P1 period (upper row; a-c) and the P2 period (lower row; $\mathbf{d}-\mathbf{f}$ ) from CTL (left column, a, d) and CPL (middle column, b, e) simulations and from satellite observations (right column, $\mathbf{c}, \mathbf{f}$ )

2009). Due to a still fairly coarse horizontal resolution of the ERA-interim reanalysis (about $75 \mathrm{~km}$ ), the ERAinterim wind speed is too smooth and weak during the Mistral event and therefore, the SST of the CTL simulation is also too smooth and warm at the exit of the Rhône valley (Fig. 5a, c). Elsewhere, the ERA-interim SST displays a significant cold bias with respect to the observations. The CPL simulation displays a more realistic SST field (Fig. 5b, c) but underestimates the SST along the Liguro-Provencal current, east of the Rhône valley exit $\left(-0.7\right.$ to $\left.-0.5^{\circ} \mathrm{C}\right)$ and overestimates the SST further south $\left(+0.5\right.$ to $\left.+0.7^{\circ} \mathrm{C}\right)$.

During the P2 period, the SST warms up everywhere due to a much weaker wind (Fig. 2c, d), a stronger downward solar flux, and to the shallow oceanic mixed layer depth which favors a fast response to any change of the atmospheric forcing. The cold SST anomaly however remains due to the trapping by the oceanic cyclonic gyre in the Gulf of Lions (e.g. Lebeaupin-Brossier et al. 2013). The signature of the preceding Mistral event on the SST pattern is however smoothed and damped due to SST redistribution by the regional oceanic circulation. During this period, the SST underestimation of the CTL simulation is even more striking than during the $\mathrm{P} 1$ period (21-23 June 2001), especially east of $5^{\circ} \mathrm{E}$ (about $-2{ }^{\circ} \mathrm{C}$ ) and the SST pattern is too 
homogeneous and smooth (Fig. 5d, f). The east-west SST gradient is present in the CPL simulation with however a too warm SST in the region of the persisting cold anomaly $\left(+1^{\circ}\right)$ and a fairly accurate value of SST east of $5^{\circ} \mathrm{E}$.

The modifications of the SST due to atmosphere/ocean coupling are visible over the whole investigated domain and therefore at a distance of typically $100 \mathrm{~km}$ from the shore where they can affect the atmospheric response and the land-sea breeze system (Rotunno 1983; Drobinski and Dubos 2009).

\subsection{SST variability}

The ERA-interim SST reanalysis is provided to WRF RCM on a daily basis. Even though the heat capacity of water is much higher than that of air, the diurnal evolution of SST might have an influence on the breeze circulation. Figure 6 shows time series of SST averaged over the Mediterranean Sea in the zoom of Fig. 1 and at two different locations:

- at $3.62^{\circ} \mathrm{E} / 42.50^{\circ} \mathrm{N}$ in the cold SST anomaly produced by the Mistral during the P1 period (21-23 June 2001) (see point S1 in Fig. 1)

- at $5.52^{\circ} \mathrm{E} / 42.15^{\circ} \mathrm{N}$, south of Marseille, in a region where the CTL SST is colder than the CPL SST (see point S2 in Fig. 1).

In ERA-interim reanalysis, we clearly see the absence of SST variation at a frequency higher than the diurnal frequency. The ERA-interim SST displays a stair-like shape (Fig. 6). Conversely, the 3-h coupling in the CPL simulation allows the simulation of the diurnal variation of the SST (Fig. 6).

In the "Mistral" area (point S1), the ERA-interim (CTL) SST is slightly warmer than the CPL SST but is within the diurnal variation range of the CPL SST. As the Mistral weakens, the SST increases but at a much slower rate in the CTL simulation with respect to the CPL simulation. It, however, remains within the diurnal variation range of the CPL SST until 25 June. Conversely, in the "Marseille" area (point S2), the ERA-interim (CTL) SST is much colder than the CPL SST and always outside of the diurnal variation range of the CPL SST. The SST difference increases significantly after 24 June reaching $3{ }^{\circ} \mathrm{C}$ on the night of 26-27 June. The fact that CPL SST remains closer to CTL SST in the "Mistral" area can be attributed to the cyclonic oceanic circulation in the Gulf of Lions which traps the cold water mass produced by the Mistral event and prevents its advection and dilution. The trapping of the cold water mass exists in the ERA-interim reanalysis even though it spreads horizontally over a too large area. The presence of the persisting cold water mass explains why there is a better agreement between the CPL and CTL SSTs in the "Mistral" area than in the "Marseille" area. The coupling however produces a more accurate pattern with more realistic meso-scale structures and time variation. Figure 6 shows that the coupling produces a SST minimum around 1200 UTC and a SST maximum shortly before 0000 UTC. SST is thus almost $6 \mathrm{~h}$ behind the near-surface air temperature, most probably due to the low thermal diffusivity of water.

Figure 7 displays the standard deviation $\sigma_{\delta S S T}$ of the CPL-CTL SST difference over P1 and P2 periods. The standard deviation quantifies the spatial variability of the difference between the two SSTs. During P1 period, when the average bias between the two simulations is the lowest, the value of the standard deviation can be mainly attributed to the diurnal cycle.

In detail, the zone of highest variability south of $42.5^{\circ} \mathrm{N}$ along the Spanish coast, is due to the shrinking of the cold SST anomaly produced at night by the Mistral blowing over the sea. The Mistral is the strongest on 22 June and weakens

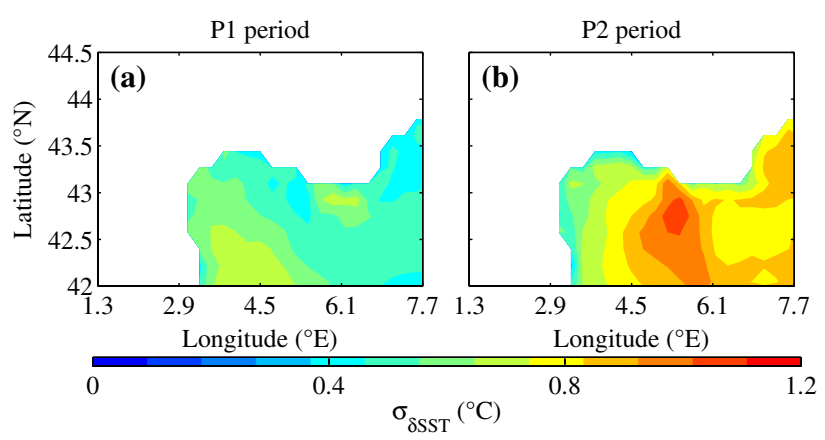

Fig. 7 Standard deviation of the CPL-CTL SST difference $\sigma_{\delta S S T}$ over P1 (a) and P2 (b) periods
Fig. 6 SST time series from CTL (ERA-interim SST; solid line) and CPL (dashed line) simulations in a the "Mistral" area (S1 location), b the "Marseille" area (S2 location) and c averaged over the whole domain (rectangle in Fig. 1)

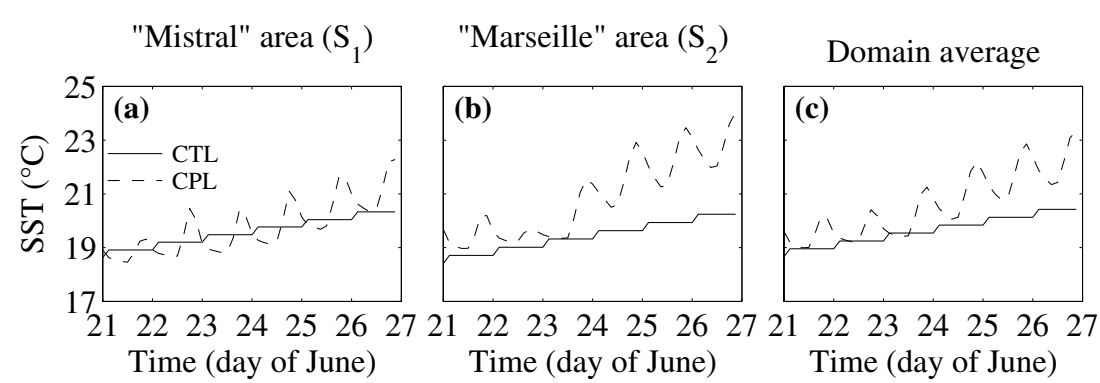




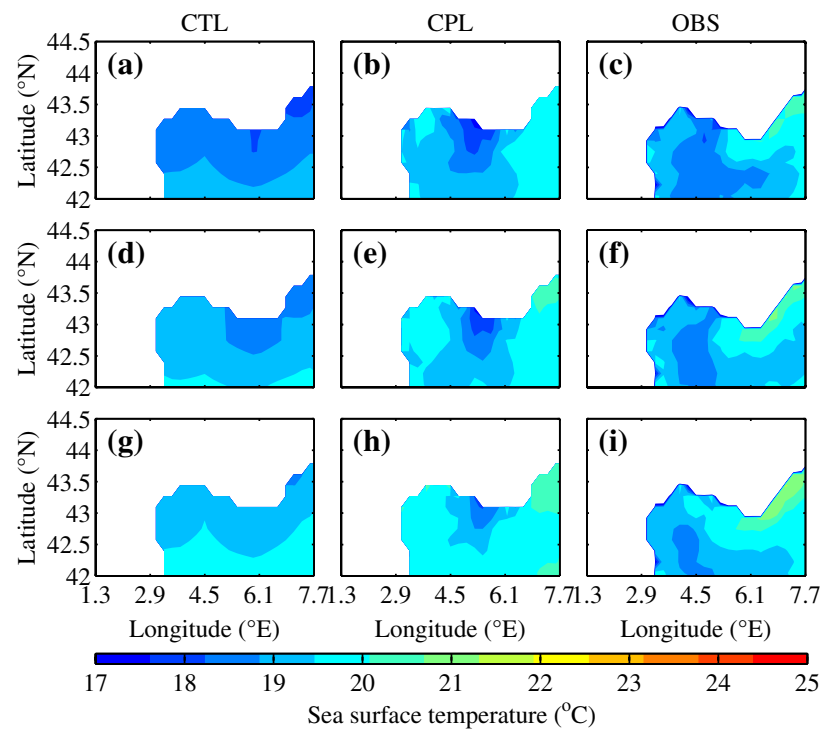

Fig. 8 SST field from CTL (left column, a, d, g) and CPL (middle column, b, e, h) simulations and from satellite observations (right column, $\mathbf{c}, \mathbf{f}, \mathbf{i}$ ) on 21 (upper row, a-c), 22 (middle row, $\mathbf{d}-\mathbf{f}$ ) and 23 June (lower row, $\mathbf{g}-\mathbf{i}$ )

until 24 June. The shallow ocean mixed layer favors a rapid response to daytime heating. The surface water warms up in the region where the Mistral weakens the most, i.e. far south from the French coast. It is visible in Fig. 8 which displays the evolution of the SST spatial pattern from CTL and CPL simulations and from satellite observations during the P1 period. The CTL simulation produces a SST field with a north-south gradient. The SST is in general colder north of the domain along the French Mediterranean coast. Between 21 and 23 June, the SST warms quasi uniformly by about $1.5-2{ }^{\circ} \mathrm{C}$. The CPL simulation produces a northsouth oriented cold streak along the Rhône valley axis which warms up and shrinks between 21 and 23 June. The observed SST also displays a cold streak which however warms up at a much lower rate and also extends to the east, south of the domain. So outside the region of influence of the Mistral, south of the French coast, the CPL-CTL SST difference is mainly driven by the simulation of the diurnal cycle in the CPL simulation. The variability $\sigma_{\delta S S T} \sim 0.5^{\circ}$ $\mathrm{C}$ is mostly due to the diurnal cycle. It increases up to 0.7 ${ }^{\circ} \mathrm{C}$ in the region where the cold anomaly trapped within the oceanic cyclonic gyre reduces its horizontal extent.

During the P2 period, the value of $\sigma_{\delta S S T}$ increases up to $1.0^{\circ} \mathrm{C}$ and is maximum south of Marseille (see S2 in Fig. 1). It is caused by the representation of the diurnal cycle and to the stronger warming in the CPL simulation with respect to the CTL simulation. Figure 9 shows larger differences between CTL and CPL simulations, and the satellite observations. In the CTL simulation, the SST pattern is very similar to that of the $\mathrm{P} 1$ period but is much warmer.

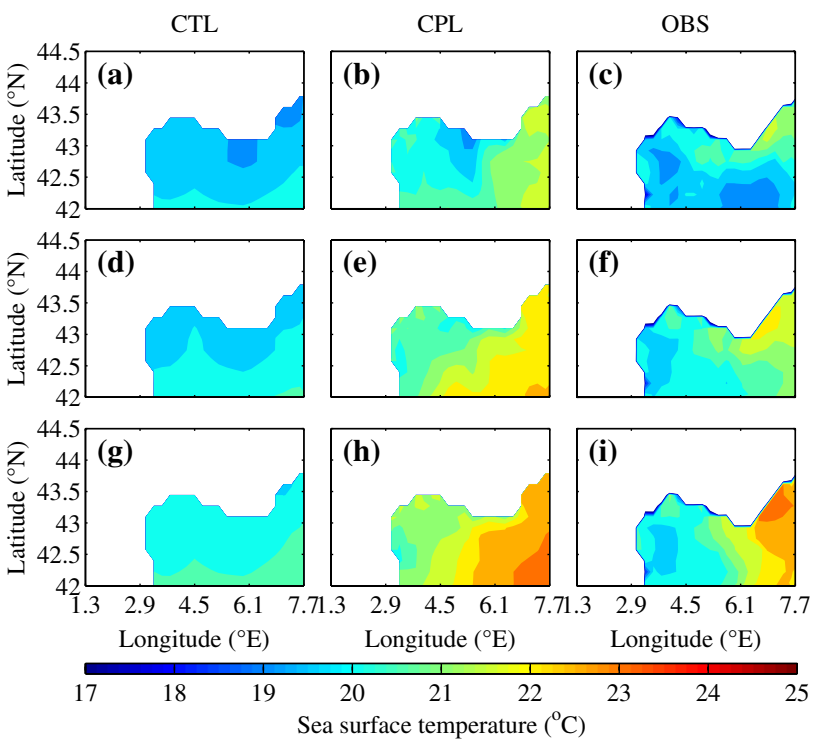

Fig. 9 Same as Fig. 8 on 24 (upper row, a-c), 25 (middle row, $\mathbf{d}-\mathbf{f}$ ) and 26 June (lower row, $\mathbf{g - i}$ )

In the CPL simulation and satellite observations, region of influence of the Mistral remains cooler and warms up at lower rate than further east. Such persisting cold anomaly is due to the cyclonic gyre trapping in the Gulf of Lions. In the east of the domain, the SST warms up quickly (3 ${ }^{\circ} \mathrm{C}$ between 24 and 26 June). It is well reproduced in the CPL simulations but it spreads too far west. If we consider that $0.5{ }^{\circ} \mathrm{C}$ variability corresponds to the SST diurnal cycle, then another $0.5^{\circ} \mathrm{C}$ can be attributed to the SST drift between the two simulations during the $\mathrm{P} 2$ period.

\section{Atmospheric response to SST in the CTL and CPL regional climate simulations}

In this section we investigate the difference of the atmospheric responses induced by the SST anomalies between the CTL and CPL simulations. Between 21 and 24 June, the CPL SST is cooler at night and warmer during daytime with respect to ERA-Interim SST. This SST difference impacts directly the temperature of the overlying air and thus the land/sea thermal contrast. Figure 10 displays the evolution of the 2-m temperature over land and over sea in the "Mistral" and the "Marseille" areas from the CTL and CPL simulations. As discussed above, the 2-m temperature over the sea is significantly affected by air/sea coupling. It is however not the case over land, where near-surface air temperature is dominantly controlled by local surface sensible heat flux which are high in the region in summer. Indeed, differences between CTL and CPL 2-m temperature are the highest in the middle of the day and never exceed 


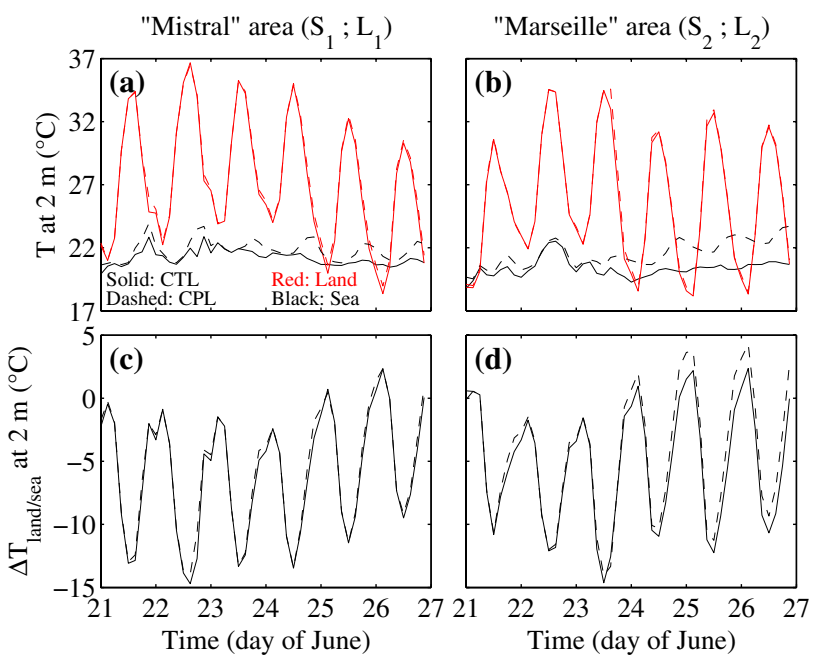

Fig. 10 Upper row Evolution of 2-m temperature over land (red line) and over sea (black line) in the "Mistral" (a) and the "Marseille" (b) areas from the CTL (solid line) and CPL (dashed line) simulations. Lower row Evolution of the land/sea thermal contrast in the "Mistral" $\left(\mathrm{S}_{1}-\mathrm{L}_{1}\right)(\mathbf{c})$ and the "Marseille" $\left(\mathrm{S}_{2}-\mathrm{L}_{2}\right)(\mathbf{d})$ areas from the CTL (solid line) and CPL (dashed line) simulations

few tenths of a degree. On average, in the "Mistral" area over the sea, the CTL and CPL 2-m temperature are similar until 24 June only differing by the diurnal amplitude due to the SST diurnal cycle in the CLP simulation. After 24 June, the two time series depart from each other (the CPL 2-m temperature being about $1{ }^{\circ} \mathrm{C}$ warmer on 25 and 26 June than the CTL 2-m temperature). In the "Marseille" area, a similar behaviour is found until 24 June. However, the difference between the CTL and CPL 2-m temperature is much larger after 24 June than in the "Mistral" area. It reaches on average $2{ }^{\circ} \mathrm{C}$ with a peak of more than $3{ }^{\circ} \mathrm{C}$ during the night of 27 June. The effect of air/sea coupling also tends to increase the diurnal variability of the near-surface air temperature over the sea. Indeed, the surface heat flux is a function of the temperature difference between the sea surface and the overlying air. With a constant SST during the day, the relaxation of the air temperature towards the constant SST produced by the flux parameterization damps the air temperature variation. The air temperature variation is only controlled by the diurnal variation of the net radiative flux. When air/sea coupled processes are accounted for, the diurnal variation of the SST amplifies the atmospheric response. On average, the difference is typically -0.5 and $+0.5^{\circ} \mathrm{C}$ at sunrise and sunset, respectively, but can reach 2 ${ }^{\circ} \mathrm{C}$ in magnitude after 24 June in the "Marseille" area. The land-sea contrast is thus modified between CTL and CPL simulations (Fig. 10c, d). It is computed as the difference between the 2-m temperature between $\mathrm{L}_{1}$ and $\mathrm{S}_{1}$ for the "Mistral" area and between $\mathrm{L}_{2}$ and $\mathrm{S}_{2}$ for the "Marseille" area. This figure shows that in the absence of coupling, the
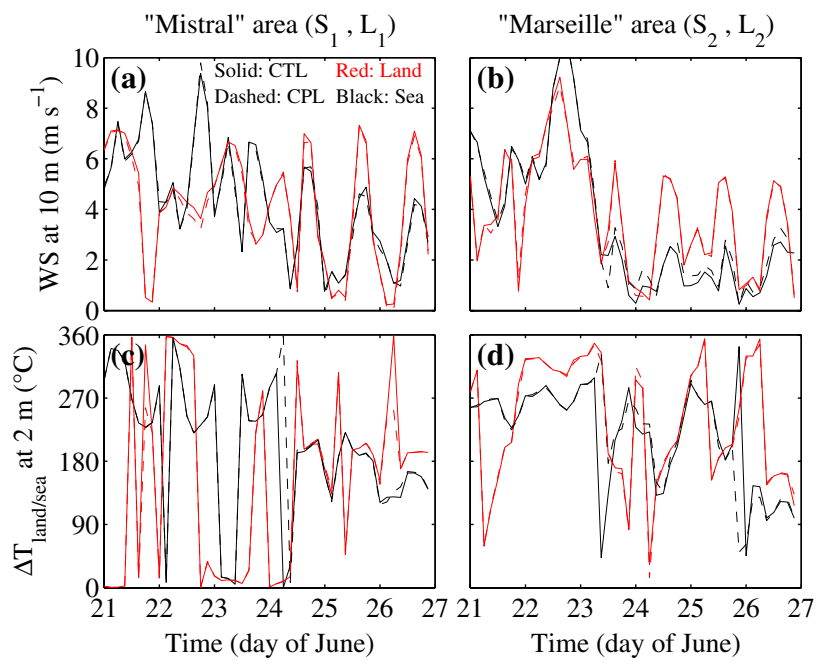

Fig. 11 Upper row Evolution of 10-m wind speed over land (red line) and over sea (black line) in the "Mistral" (a) and the "Marseille" (b) areas from the CTL (solid line) and CPL (dashed line) simulations. Lower row Evolution of 10-m wind direction over land (red line) and over sea (black line) in the "Mistral" (c) and the "Marseille" (d) areas from the CTL (solid line) and CPL (dashed line) simulations

diurnal amplitude of the thermal contrast reaches about 12 ${ }^{\circ} \mathrm{C}$, whereas it is about $10 \%$ larger when air/sea coupling is accounted for (it can even reach $20 \%$ between 24 and 26 June in the "Marseille" area).

How these $10 \%$ additional thermal contrast impact the sea-breeze circulation is one key question. Figure 11 shows the near surface wind speed and direction from the CTL and CPL simulations at the "Mistral" and "Marseille" areas. The only visible differences are over the sea during the P2 period and are larger in the "Marseille" area than in the "Mistral" area, consistently with the near-surface air temperature difference. Conversely, over land, as for the temperature, there is no visible impact of the SST anomalies on the wind speed. The $10 \%$ additional thermal contrast is too localized and of too weak magnitude to affect significantly the sea-breeze circulation at large scale.

What happens over the sea is similar to the local atmospheric response to fine oceanic thermal front which generate thermal winds over the sea (Giordani and Planton 2000). The magnitude of SST anomalies produces local but significant modifications of the offshore wind. The modification of the offshore wind speed can reach $20 \%$ during the P2 period in the "Marseille" area but does not extend over large distance.

The modification of the offshore wind speed can reach $20 \%$ during the P2 period in the "Marseille" area but this modification is confined to the streak thermal anomaly of few tens of kilometers size. Such confined response is similar to what would be expected for an oceanic thermal fron, 
it is significant in magnitude but does not extend over the typical 100-150 km distance expected for the large-scale sea-breeze.

To analyze more thoroughly the atmospheric response to the SST anomaly, we consider the evolution of the temperature anomaly of CPL relative to CTL in the lowest model layers which is given by the following equation:

$\frac{\partial T_{C P L-C T L}}{\partial t}=-\quad \underbrace{u_{C T L} \nabla T_{C P L-C T L}}$

Advection of $\mathrm{T}$ anomalies (term I)

$$
-\quad \underbrace{u_{C P L-C T L} \nabla T_{C T L}}
$$

Advection of $\mathrm{T}$ by wind anomalies (term II)

$$
-
$$

Advection of $\mathrm{T}$ anomalies by wind anomalies (term III)

$$
+\underbrace{H F_{C P L-C T L}}_{\text {Turbulent heat flux anomalies (term IV) }}
$$

Similar equations can be written for water mixing ratio and wind components. Figure 12 displays the standard deviations $\sigma_{\delta T_{2}}$ of the CPL-CTL 2-m temperature difference over the $\mathrm{P} 1$ and $\mathrm{P} 2$ periods. The 2-m temperature difference variability $\sigma_{\delta T_{2}}$ over the sea shows a strong correlation with $\sigma_{\delta S S T}$ (i.e. 0.58 and 0.75 for the $\mathrm{P} 1$ and $\mathrm{P} 2$ periods, respectively). During the P1 period, the temperature anomaly variability penetrates inland in the "Marseille" area over a distance corresponding to one grid cell only. Even though we are at the limit of sensitivity with regards to the penetration distance, it remains consistent with observations or simulations performed at kilometer scale horizontal resolution (Bastin and Drobinski 2006). The presence of the Mistral does not allow sea-breeze inland penetration in the

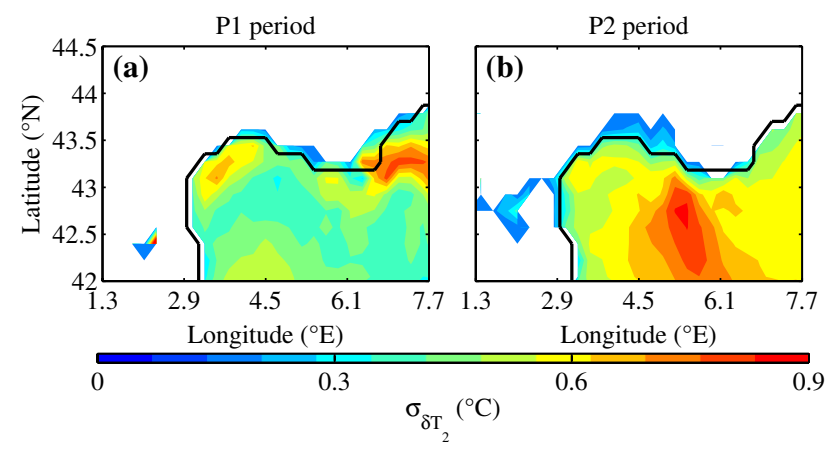

Fig. 12 Significant standard deviation of the CPL-CTL 2-m temperature difference during the $\mathrm{P} 1$ period (a) and the $\mathrm{P} 2$ period (b)
Rhône valley delta. During the P2 period, no adverse wind prevents inland penetration of the sea-breeze. The largest penetration occurs along the Rhône valley axis as no mountain surrounding the Mediterranean coast prevents inland penetration (Bastin et al. 2005a, b). During the P2 period, most of the temperature anomaly variability penetrates over land in the "Mistral" area and not in the "Marseille" area.
Surprisingly, Fig. 13 which is similar to Fig. 12 for the wind speed anomaly, does not exhibit a similar spatial pattern as in Fig. 12. The largest variability is found over the sea where the perturbation by the SST anomaly is the largest, but over land, there is no significant effect of the SST difference on the wind speed anomaly, or in other words on the onshore penetration of the sea-breeze. From Eq. (1), this suggests that the advection of $T$ anomalies (term I) dominates over the advection of $T$ by wind anomalies (term II). The advection of $T$ anomalies by wind anomalies (term III) is strongly non linear and of much lower magnitude than terms I and II. The turbulent heat flux anomalies (term IV) are totally negligible as the heat fluxes are very large over land and are not modulated by any inland advection of temperature anomaly. The large surface heat fluxes over

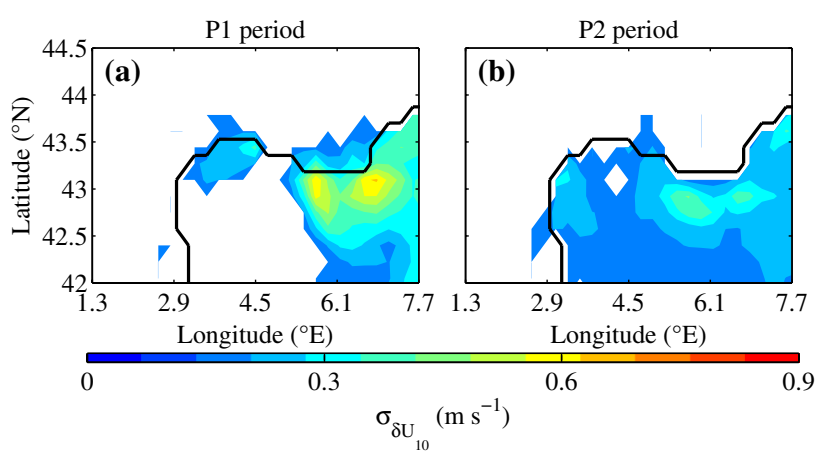

Fig. 13 Same as Fig. 12 for the 10-m wind speed difference 


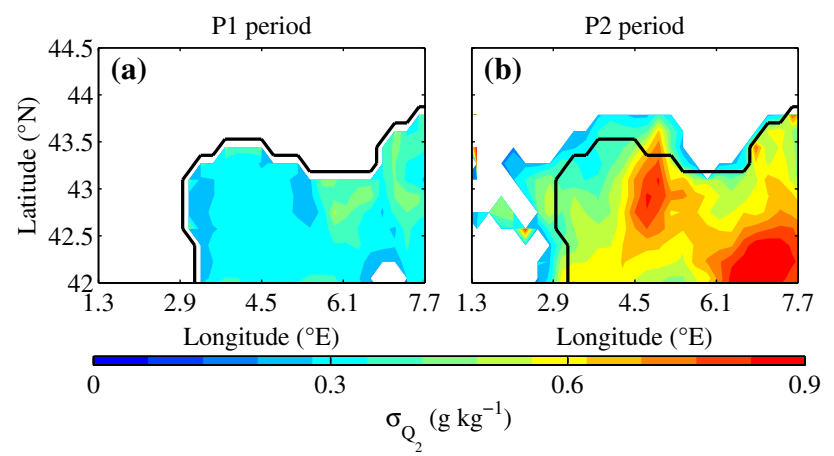

Fig. 14 Same as Fig. 12 for the 2-m water vapor mixing ratio

land also explain why the temperature anomaly is not seen further inland. Indeed, the large heat fluxes warm up the overlying air very quickly so that after some distance from the shore, the temperature anomaly vanishes.

Finally, Fig. 14 shows the effect of the SST difference on the water mixing ratio. Interestingly, the water mixing ratio anomaly pattern differs from both that for the temperature and wind speed. For the P1 period, the pattern is similar to that for temperature and wind speed. No anomaly of moisture penetrates significantly onshore. For the P2 period, water mixing ratio anomaly penetrates inland over a larger area around the Mediterranean coast, consistently with the sea-breeze wind system (Fig. 2). Indeed, for a given atmospheric forcing, evaporation over the sea depends on the SST. Anomalies of water mixing ratio over the sea are therefore in part associated with the SST anomaly pattern. Such anomalies penetrate inland by the sea breeze (term I of the water vapor anomaly conservation equation similar to Eq. (1)). The anomaly only experiences vertical dilution due to deeper boundary layer over land without additional water vapor source because of the very low evapo-transpiration at this period of the year due to aridity. So contrary to the temperature, there is no mechanism which damps the difference of water vapor mixing ratio between the CTL and CPL simulations.

Figure 15 shows a vertical cross sections of potential temperature along the "Mistral" area and the "Marseille" area. The first noticeable feature is the depth over which the anomaly is significant. It is much shallower than the sea-breeze which depth is around $1 \mathrm{~km}$ for these days (Drobinski et al. 2006; see also Figs. 3, 4). This suggests the importance of the shallow sea-breeze in the dilution and advection of the near-surface anomalies produced by SST difference. Indeed, within the shallow breeze, mixing is produced by near-surface vertical shear of wind speed (Bastin and Drobinski 2006). The shallow sea-breeze then advects onshore the temperature anomaly over a fairly shallow depth $(<250 \mathrm{~m})$, which thus limits the inland penetration of the anomaly. Indeed, this shallow layer is very

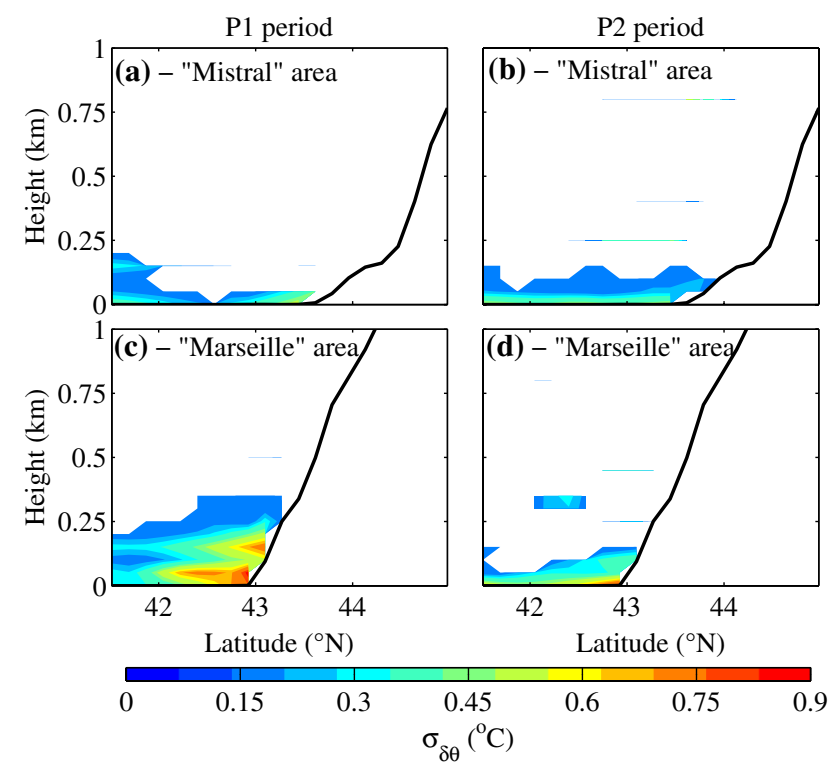

Fig. 15 Vertical cross sections of potential temperature along the "Mistral" area (L1, S1) (a, c) and the "Marseille" area (L2, S2) (b, d) for the P1 period (a, b) and the P2 period (c, d). The thick line indicates the ground surface height

responsive to inland surface heating which damps the anomaly. Similar results have been obtained with the water vapor anomaly (not shown).

\section{Generalization}

During the ESCOMPTE campaign, 4 other IOPs have been documented with a large instrument deployment as they corresponded to situation of high pollution levels (Cros et al. 2004). The first IOP (IOP1) occurred between 14 and 15 June 2001, but was considered as a test for the whole ESCOMPTE experimental set up. IOP3 occurred 2 and 4 July 2001 and IOP4 between 10 and 13 July 2001. The situations described in the P2 period of IOP2 (25-26 June 2001) are the two main typical situations documented during the whole ESCOMPTE observing period between 10 June to 13 July 2011. During the P1 period of IOP2 (21- 23 June 2001), a weak mistral blows over the target area. This situation is very similar to the other cases with offshore prevailing wind when the sea-breeze does not reach the main valleys channeling the air flow in this region (Aude, Rhne and Durance valleys mainly). During IOP3 (2-4 July 2001), a moderate southerly synoptic flow blows, which is a situation very similar to that of 26 June of IOP2. The surface wind and temperature pattern is nearly the same. IOP4 (10-13 July 2001) was launched under hot temperature and clear sky conditions but with a westerly/ northwesterly synoptic wind confining the sea breeze only 
Table 1 Sea-breeze inland penetration, intensity and depth at 1700 UTC (maximum penetration) as observed from the Météo-France surface weather station network, ground-based wind profilers (radar, lidar) and airborne Doppler lidar and as simulated in the CTL and CPL configurations

\begin{tabular}{|c|c|c|c|c|c|c|}
\hline \multirow[t]{2}{*}{ Date } & \multicolumn{2}{|c|}{$\begin{array}{l}\text { Breeze inland penetration } \\
(\mathrm{km})\end{array}$} & \multicolumn{2}{|c|}{ Breeze intensity $\left(\mathrm{m} \mathrm{s}^{-1}\right)$} & \multicolumn{2}{|c|}{ Breeze depth $(\mathrm{km})$} \\
\hline & OBS & CTL/CPL & OBS & CTL/CPL & OBS & CTL/CPL \\
\hline \multicolumn{7}{|l|}{ IOP1 } \\
\hline 14 June & 80 & $80 / 70$ & - & $5.3 / 5.4$ & - & $0.6 / 0.6$ \\
\hline 15 June & 90 & $100 / 100$ & - & $11.8 / 11.8$ & - & $0.4 / 0.4$ \\
\hline \multicolumn{7}{|l|}{ IOP2a } \\
\hline 21 June & 50 & $50 / 50$ & 9.2 & $11.4 / 11.3$ & 0.8 & $0.5 / 0.5$ \\
\hline 22 June & 50 & $40 / 40$ & 9.7 & $9.8 / 9.6$ & 0.7 & $0.8 / 0.8$ \\
\hline 23 June & 50 & $30 / 30$ & 7.7 & $9.2 / 9.1$ & 0.7 & $0.8 / 0.8$ \\
\hline \multicolumn{7}{|l|}{$\mathrm{IOP} 2 \mathrm{~b}$} \\
\hline 24 June & 80 & $80 / 80$ & 4.2 & $4.3 / 4.3$ & 1.2 & $1.0 / 1.0$ \\
\hline 25 June & 100 & $90 / 90$ & 3.5 & $4.0 / 4.0$ & 1.2 & $1.1 / 1.1$ \\
\hline 26 June & 120 & $120 / 120$ & 4.8 & $4.8 / 4.9$ & 1.2 & $1.2 / 1.2$ \\
\hline \multicolumn{7}{|l|}{ IOP3 } \\
\hline 2 July & 70 & $80 / 80$ & - & $2.4 / 2.5$ & - & $1.5 / 1.5$ \\
\hline 3 July & 110 & $100 / 100$ & 3.5 & $3.4 / 3.4$ & 1.5 & $1.5 / 1.5$ \\
\hline 4 July & 150 & $110 / 110$ & 6.5 & $8.1 / 8.0$ & 1.5 & $1.1 / 1.1$ \\
\hline \multicolumn{7}{|l|}{ IOP4 } \\
\hline 10 July & 100 & $90 / 90$ & - & $3.5 / 3.4$ & - & $0.9 / 0.9$ \\
\hline 11 July & 30 & $30 / 30$ & - & $14.3 / 14.1$ & - & $0.7 / 0.7$ \\
\hline 12 July & 80 & $50 / 50$ & - & 11.7/11.6 & - & $0.7 / 0.7$ \\
\hline 13 July & 100 & $70 / 70$ & - & $6.4 / 6.4$ & - & $0.9 / 0.9$ \\
\hline
\end{tabular}

The observed sea breeze intensity and depth are retrieved from the profilers at the "Marseille" area. For both the observations and simulations, the intensity is computed as the wind speed averaged over the sea breeze depth. A "-" symbol corresponds to the absence of the necessary measurements to derived the sea breeze depth (either not existing or no longer available). Due to the distance between surface weather station and the size of the model grid, the uncertainty of the sea-breeze inland penetration is larger than 20 $\mathrm{km}$. The value was therefore rounded to the nearest ten in the vicinity of the Marseille area. Table 1 compares the breeze inland penetration in the Rhône valley deduced from the surface weather station network and from the surface wind and temperature from the CTL and CPL simulations. It is one key feature of the sea-breeze and is computed as the distance along the Rhône valley axis between the shore and the location of the temperature maximum or/and (when it exists) the area where the wind reverses from the south (sea breeze flow) to the north (Drobinski et al. 2006). A second essential characteristics of the sea-breeze is its depth and its intensity retrieved from the UHF or ground based lidar in the Marseille area (e.g. Bastin et al. 2006, 2007) or from airborne Doppler lidar (Drobinski et al. 2006). The breeze intensity is computed as the height averaged wind speed between the ground and the sea-breeze depth. The sea-breeze depth is estimated from the UHF or lidar wind profiles as the height of the transition between the upper-level synoptic flow which exhibits a strong wind direction shift and an increase of the wind speed. In situations when the synoptic flow and the sea breeze blow in the same direction, we use the PBL depth as a tracer of the sea breeze depth using the lidar signal and following the method described in Morille et al. (2007). Since the UHF profilers and the lidars were not available during the whole campaign, the sea-breeze depth and intensity are not available for all IOPs. As for IOP2, the two simulations (CTL and CPL) in general accurately reproduce the main sea breeze characteristics with differences between the two simulations ranging between 5 and $20 \%$ which significance is difficult to assess because of the model horizontal resolution and the surface weather station density. The inland penetration during IOP4 is underestimated by about 30-35\% in the simulations. However, due the strong westerly wind which combines with the sea breeze, the estimation of the penetration is not as straightforward as for the other IOPs. As can be seen in Table 1, there is no significant difference between the CTL and CPL simulations over land as for IOP2. The air/sea coupled processes do not affect the main characteristics of the sea breeze at large scale.

Similarly to Figs. 12 and 14, Fig. 16 shows the effect of the SST difference on the temperature and water mixing ratio for the other ESCOMPTE IOPs. As for IOP2, the correlation between $\sigma_{\delta T_{2}}$ and $\sigma_{\delta S S T}$ is large. It is 0.76 for IOP1 (14-15 June), 0.79 for IOP3 (2-4 July) and 

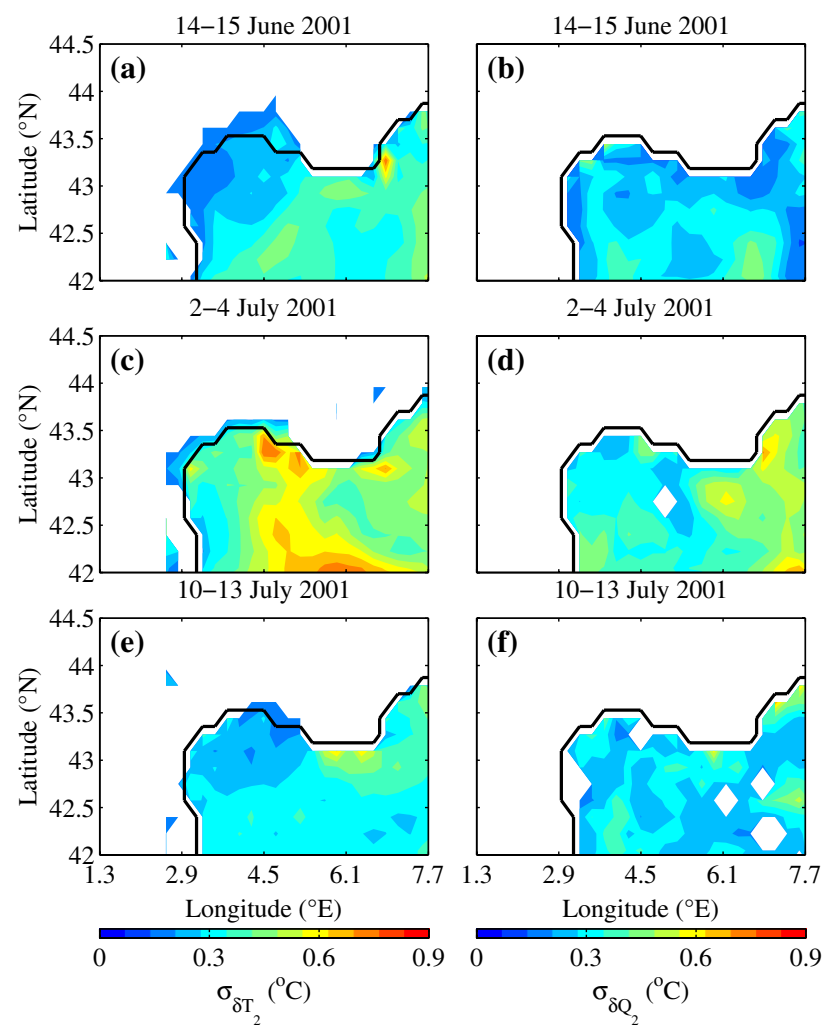

Fig. 16 Significant standard deviation of the CPL-CTL 2-m temperature difference $(\mathbf{a}, \mathbf{c}, \mathbf{e})$ and the 2-m water vapor mixing ratio difference (b, d, f) for ESCOMPTE IOP1 (14-15 June) (a, b), IOP3 (2-4 July) (c, d) and IOP4 (10-13 July) (e, f)

0.87 for IOP4 (10-13 July). However compared to IOP2, the magnitude of $\sigma_{\delta T_{2}}$ and $\sigma_{\delta Q_{2}}$ is smaller for all other IOPs. IOP1 and IOP 3 can be compared to the P2 period of IOP2. The sea breeze flow is weaker for both IOPs, however IOP1 can be compared to the first two days of the P2 period of IOP2 and IOP3 to the last day. The sea breeze penetrates farther inland than during IOP4 (i.e. around $100 \mathrm{~km}$ ). As for the $\mathrm{P} 2$ period of IOP2, the temperature anomalies, which originate directly from the SST anomalies, are advected inland over a range similar to that of the $\mathrm{P} 2$ period of IOP2. Conversely, because the amplitude of $\sigma_{\delta Q_{2}}$ is smaller than during IOP2, there is no significant inland advection of water mixing ratio anomaly for both IOP1 and IOP3. During IOP4, the northwesterly flow prevents a deep inland penetration of the sea breeze. The sea breeze breaks through around the Marseille area only without significant values of $\sigma_{\delta T_{2}}$ and $\sigma_{\delta Q_{2}}$ inland, similarly to the period P1 of IOP2. In conclusion, the impact of the SST differences on the breeze circulation is similar between all IOPs.

\section{Conclusion}

The first result of this study is that these simulations performed at $20 \mathrm{~km}$ resolution reproduce with $5-20 \%$ accuracy, the intensity, direction and inland penetration of the sea breeze and even the existence of the shallow sea breeze despite more differences due to the coarse resolution which impacts the coastline shape. The overestimate of temperature over land in both simulations, which likely affects the temperature gradient that drives the sea breeze, certainly impacts the propagation speed of the breeze, but not its horizontal extent which is mainly governed by the Rossby deformation radius during period P2 and strongly limited by the opposite Mistral flow that blows in the Rhône valley during period $\mathrm{P} 1$.

One major impact of atmosphere/ocean coupling is the simulation of the diurnal variation of SST. Because of the fine scale resolution of the MORCE plateform $(20 \mathrm{~km})$, local regional winds, like Mistral or Tramontane, largely controlled by the topography, are well simulated and their impact on air/sea exchanges also. The CPL simulation thus provides a more realistic representation of the evolution of the SST field at fine scale than the CTL one. Temperature and moisture anomalies are created in direct response to the SST anomaly. However, the SST anomalies are localized and are not of sufficient magnitude to affect the large-scale sea-breeze circulation. Only local thermal wind perturbation are created in the vicinity of the SST anomalies. Temperature and moisture anomalies are generated inland by the advection of the anomalies created over SST anomaly by the shallow sea-breeze. The temperature anomalies are quickly damped by strong surface heating over land. The water vapor mixing ratio anomalies are transported further inland due to the absence of water vapor source over land. The inland limit of significance is imposed by the vertical dilution in a deeper continental boundary-layer. The vertical extent of the anomaly corresponds to the depth where the mixing induced by the vertical shear of horizontal wind speed in the shallow sea breeze is produced.

Acknowledgements This work is a contribution to the HyMeX program (HYdrological cycle in The Mediterranean EXperiment) through INSU-MISTRALS support and the Med-CORDEX program (COordinated Regional climate Downscaling EXperiment, Mediterranean region). This research has received funding from the French National Research Agency (ANR) project REMEMBER (contract ANR-12-SENV-001) and from the MORCE-MED project funded by the GIS "Climat, Environnement et Société". It was also supported by the IPSL group for regional climate and environmental studies, with granted access to the HPC resources of IDRIS (under allocation i2011010227). The authors are very grateful to C. Lebeaupin-Brossier (CNRM), Jonathan Beuvier, Guillaume Samson (Mercator-Océan), Sébastien Masson, Gurvan Madec (LOCEAN), Sophie Valcke, Laure Coquart and Eric Maisonnave (CERFACS) for their useful collaboration in the development of the regional climate system model MORCE. The authors also thank Hervé Roquet (CMS/Météo-France), 
who provided SST satellite data, and the Climserv team from IPSL, who provided the ERA-interim reanalysis and stored the HyMeX/ MED-CORDEX simulations.

Open Access This article is distributed under the terms of the Creative Commons Attribution 4.0 International License (http:// creativecommons.org/licenses/by/4.0/), which permits unrestricted use, distribution, and reproduction in any medium, provided you give appropriate credit to the original author(s) and the source, provide a link to the Creative Commons license, and indicate if changes were made.

\section{References}

Alpert P, Stein U, Tsidulko M (1995) Role of sea fluxes and topography in eastern Mediterranean cyclo-genesis. Glob Atmos Ocean Syst 3:55-79

Arritt RW (1993) Effects of the large-scale flow on characteristics features of the sea breeze. J Appl Meteorol 32:116-125

Banta RM (1995) Sea breezes shallow and deep on the california coast. Mon Weather Rev 123:3614-3622

Bastin S, Drobinski P (2005) Temperature and wind velocity oscillations along a gentle slope during sea-breeze events. Bound Layer Meteorol 114:573-594

Bastin S, Drobinski P (2006) Sea breeze induced mass transport over complex terrain in southeastern France: a case study. Q J R Meteorol Soc 132:405-423

Bastin S, Drobinski P, Dabas AM, Delville P, Reitebuch O, Werner C (2005a) Impact of the Rhône and Durance valleys on sea-breeze circulation in the Marseille area. Atmos Res 74:303-328

Bastin S, Champollion C, Bock O, Drobinski P, Masson F (2005b) On the use of GPS tomography to investigate water vapor variability during a Mistral/sea breeze event in Southeastern France. Geophys Res Let 32:L05808. doi:10.1029/2004GL021907

Bastin S, Drobinski P, Guénard V, Caccia JL, Campistron B, Dabas AM, Delville P, Reitebuch O, Werner C (2006) On the interaction between sea breeze, and summer Mistral at the exit of the Rhône valley. Mon Weather Rev 134:1647-1668

Bastin S, Champollion C, Bock O, Drobinski P, Masson F (2007) Diurnal cycle of water vapor as documented by a dense GPS network in a coastal area during ESCOMPTE-IOP2. J Appl Meteorol Climatol 46:167-182

Berthou S, Mailler S, Drobinski P, Arsouze T, Bastin S, Béranger K, Flaounas E, Lebeaupin Brossier C, Somot S, Stéfanon M (2016) Influence of submonthly air-sea coupling on heavy precipitation events in the Western Mediterranean basin. Q J R Meteorol Soc 142(Suppl 1):453-471

Berthou S, Mailler S, Drobinski P, Arsouze T, Bastin S, Béranger K, Lebeaupin-Brossier C (2015) Sensitivity of an intense rain event between an atmosphere-only and an atmosphere-ocean coupled model: 19 September 1996. Q J R Meteorol Soc 141:258-271

Berthou S, Mailler S, Drobinski P, Arsouze T, Bastin S, Béranger K, Lebeaupin-Brossier C (2014) Prior history of Mistral and Tramontane winds modulates heavy precipitation events in Southern France. Tellus 66:24064

Beuvier J, Sevault F, Herrmann M, Kontoyiannis H, Ludwig W, Rixen M, Stanev E, Béranger K, Somot S (2010) Modelling the Mediterranean Sea interannual variability during 1961-2000: focus on the Eastern Mediterranean Transient (EMT). J Geophys Res 115:C08517. doi:10.1029/2009JC005850

Brankart JM, Brasseur P (1998) The general circulation in the Mediterranean Sea: a climatological approach. J Mar Syst 18:41-70
Claud C, Alhammoud B, Funatsu BM, Lebeaupin-Brossier C, Chaboureau JP, Béranger K, Drobinski P (2012) A high resolution climatology of precipitation and deep convection over the Mediterranean region from operational satellite microwave data: Development and application to the evaluation of model uncertainties. Nat Hazards Earth Syst Sci 12:785-798

Corsmeier U, Behrendt R, Drobinski P, Kottmeier C (2005) The Mistral and its effect on air pollution transport and vertical mixing. Atmos Res 74:275-302

Cros B, Durand P, Cachier H, Drobinski P, Frejafon E, Kottmeier C, Perros PE, Peuch VH, Ponche JL, Robin D, Saïd F, Toupance G, Wortham H (2004) The ESCOMPTE program: an overview. Atmos Res 69:241-279

Dalu GA, Pielke RA (1989) An analytical study of the sea breeze. J Atmos Sci 46:1815-1825

Dee D, Uppala S, Simmons A, Berrisford P, Poli P, Kobayashi S, Andrae U, Balmaseda M, Balsamo G, Bauer P, Bechtold P, Beljaars ACM, van de Berg L, Bidlot J, Bormann N, Delsol C, Dragani R, Fuentes M, Geer AJ, Haimberger L, Healy SB, Hersbach H, Hólm EV, Isaksen L, Kållberg P, Köhler M, Matricardi M, McNally AP, Monge-Sanz BM, Morcrette JJ, Park BK, Peubey C, de Rosnay P, Tavolato C, Thépaut JN, Vitart F (2011) The ERA-Interim reanalysis: configuration and performance of the data assimilation system. Q J R Meteorol Soc 137:553-597

Di Luca A, Flaounas E, Drobinski P, Lebeaupin Brossier C (2014) The atmospheric component of the Mediterranean Sea water budget in a WRF physics ensemble and observations. Clim Dyn 43:2349-2375

Drobinski P, Da Silva N, Panthou G, Bastin S, Muller C, Ahrens B, Borga M, Conte D, Fosser G, Giorgi F, Güttler I, Kotroni V, Li L, Morin E, Onol B, Quintana-Segui P, Romera R, Torma CZ (2016) Scaling precipitation extremes with temperature in the Mediterranean: Past climate assessment and projection in anthropogenic scenarios. Clim Dyn. doi:10.1007/s00382-016-3083-x

Drobinski P, Ducrocq V, Alpert P, Anagnostou E, Béranger K, Borga M, Braud I, Chanzy A, Davolio S, Delrieu G, Estournel C, Filali Boubrahmi N, Font J, Grubisic V, Gualdi S, Homar V, IvancanPicek B, Kottmeier C, Kotroni V, Lagouvardos K, Lionello P, Llasat MC, Ludwig W, Lutoff C, Mariotti A, Richard E, Romero R, Rotunno R, Roussot O, Ruin I, Somot S, Taupier-Letage I, Tintore J, Uijlenhoet R, Wernli H (2014) HyMeX, a 10-year multidisciplinary program on the Mediterranean water cycle. Bull Am Meteorol Soc 95:1063-1082

Drobinski P, Anav A, Lebeaupin Brossier C, Samson G, Stéfanon M, Bastin S, Baklouti M, Béranger K, Beuvier J, Bourdallé-Badie R, Coquart L, D’Andrea F, De Noblet-Ducoudré N, Diaz F, Dutay JC, Ethe C, Foujols MA, Khvorostyanov D, Madec G, Mancip M, Masson S, Menut L, Palmieri J, Polcher J, Turquety S, Valcke S, Viovy N (2012) Modelling the regional coupled Earth system (MORCE): application to process and climate studies in vulnerable regions. Env Model Softw 35:1-18

Drobinski P, Rotunno R, Dubos T (2011) Linear theory of the sea breeze in a thermal wind. Q J R Meteorol Soc 137:1602-1609

Drobinski P, Dubos T (2009) Linear breeze scaling: from large-scale land/sea breezes to mesoscale inland breezes. Q J R Meteorol Soc 135:1766-1775

Drobinski P, Saïd F, Ancellet G, Arteta J, Augustin P, Bastin S, Brut A, Caccia JL, Campistron B, Cautenet S, Colette A, Coll I, Cros B, Corsmeier U, Dabas A, Delbarre H, Dufour A, Durand P, Guénard V, Hasel M, Kalthoff N, Kottmeier C, Lemonsu A, Lasri F, Lohou F, Masson V, Menut L, Moppert C, Peuch VH, Puygrenier V, Reitebuch O, Vautard R (2007) Regional transport and dilution during high pollution episodes in southern France: summary of findings from the ESCOMPTE experiment. J Geophys Res 112:D13105. doi:10.1029/2006JD007494 
Drobinski P, Bastin S, Dabas AM, Delville P, Reitebuch O (2006) Variability of the three-dimensional sea-breeze structure in southeastern France: observations and evaluation of empirical scaling laws. Ann Geophys 24:1783-1799

Drobinski P, Bastin S, Guénard V, Caccia JL, Dabas AM, Delville P, Protat A, Reitebuch O, Werner C (2005) Summer Mistral at the exit of the Rhône valley. Q J R Meteorol Soc 131:353-375

Drobinski P, Flamant C, Dusek J, Flamant PH, Pelon J (2001) Observational evidence and modeling of an internal hydraulic jump at the atmospheric boundary layer top during a Tramontane event. Bound Layer Meteorol 98:497-515

Dudhia J (1989) Numerical study of convection observed during the winter monsoon experiment using a mesoscale two-dimensional model. J Atmos Sci 46:3077-3107

Estoque MA (1962) The sea breeze as a function of the prevailing synoptic situation. J Atmos Sci 19:244-250

Flaounas E, Drobinski P, Vrac M, Bastin S, Lebeaupin-Brossier C, Stéfanon M, Borga M, Calvet JC (2013) Precipitation and temperature space-time variability and extremes in the Mediterranean region: evaluation of dynamical and statistical downscaling methods. Clim Dyn 40:2687-2705

Giordani H, Planton S (2000) Modeling and analysis of ageostrophic circulation over the Azores oceanic front during the SEMAPHORE experiment. Mon Wea Rev 128:2270-2287

Guénard V, Drobinski P, Caccia J-L, Tedeschi G, Currier P (2006) Dynamics of the MAP IOP-15 severe Mistral event: observations and high-resolution numerical simulations. Q J R Meteorol Soc 132:757-778

Guénard V, Drobinski P, Caccia JL, Campistron B, Bénech B (2005) An observational study of the mesoscale Mistral dynamics. Bound Layer Meteorol 115:263-288

Hong S, Dudhia J, Chen S, Korea S (2004) A revised approach to ice microphysical processes for the bulk parameterization of clouds and precipitation. Mon Wea Rev 132:103-120

Kain JS (2004) The Kain-Fritsch convective parameterization: an update. J Appl Meteorol 43:170-181

Kusuda M, Alpert P (1983) Anti-clockwise rotation of the wind hodograph. Part I: Theoretical study. Atmos Environ 32:2071-2087

Lebeaupin-Brossier C, Drobinski P, Béranger K, Bastin S (2015) Regional mesoscale air-sea coupling impacts and extreme meteorological events role on the Mediterranean Sea water budget. Clim Dyn 44:1029-1051

Lebeaupin-Brossier C, Drobinski P, Béranger K, Bastin S, Orain F (2013) Ocean memory effect on the dynamics of coastal heavy precipitation preceded by a Mistral event in the North-Western Mediterranean. Q J R Meteorol Soc 139:1583-1597

Lebeaupin Brossier C, Béranger K, Drobinski P (2012) Sensitivity of the north-western Mediterranean coastal and thermohaline circulations as simulated by the $1 / 12^{\circ}$ resolution oceanic model NEMO-MED12 to the space-time resolution of the atmospheric forcing. Ocean Model 43-44:94-107

Lebeaupin Brossier C, Béranger K, Drobinski P (2012) Ocean response to strong precipitation events in the Gulf of Lions (north-western Mediterranean Sea): A sensitivity study. Ocean Dyn 62:213-226

Lebeaupin Brossier C, Béranger K, Deltel C, Drobinski P (2011) The Mediterranean response to different space-time resolution atmospheric forcings using perpetual mode sensitivity simulations. Ocean Model 36:1-25

Lebeaupin Brossier C, Drobinski P (2009) Numerical high-resolution air-sea coupling over the Gulf of Lions during two Tramontane/ Mistral events. J Geophys Res 114:D10110. doi:10.1029/200 8JD011601

Lebeaupin Brossier C, Ducrocq V, Giordani H (2009) Two-way one-dimensional high-resolution air-sea coupled modelling applied to Mediterranean heavy rain events. Q J R Meteorol Soc 135:187-204

Lebeaupin Brossier C, Ducrocq V, Giordani H (2008) Sensitivity of three Mediterranean heavy rain events to two different sea surface fluxes parameterizations in high-resolution numerical modeling. J Geophys Res 113:D21109. doi:10.1029/2007JD009613

Lebeaupin C, Ducrocq V, Giordani H (2006) Sensitivity of Mediterranean torrential rain events to the sea surface temperature based on high-resolution numerical forecasts. J Geophys Res 111:D12110. doi:10.1029/2005JD006541

Lemonsu A, Bastin S, Masson V, Drobinski P (2006) Vertical structure of the urban boundary layer over Marseille under sea breeze conditions. Bound Layer Meteorol 118:477-501

Levitus S, Antonov JI, Boyer TP (2005) Warming of the world ocean. Geophys Res Lett 32:L02604. doi:10.1029/2004GL021592

Madec G (2008) NEMO ocean engine. Note du Pole de modélisation, Institut Pierre-Simon Laplace (IPSL), France, No 27 ISSN No 1288-1619

Marullo S, Buongiorno Nardelli B, Guarracino M, Santoreli R (2007) Observing the Mediterranean Sea from space: 21 years of Pathfinder-AVHRR sea surface temperature (1985 to 2005): re-analysis and validation. Ocean Sci 3:299-310

Menut L, Coll I, Cautenet S (2005) Impact of meteorological data resolution on the forecasted ozone concentrations during ESCOMPTE IOP2a and IOP2b. Atmos Res 74:139-159

Mestayer P, Durand P, Augustin P, Bastin S, Bonnefond JM, Bénech B, Campistron B, Coppalle A, Delbarre H, Dousset B, Drobinski P, Druilhet A, Fréjafon E, Grimmond S, Groleau D, Irvine M, Kergomard C, Kermadi S, Lagouarde JP, Lemonsu A, Lohou F, Long N, Masson V, Moppert C, Noilhan J, Offerle B, Oke T, Pigeon G, Puygrenier V, Roberts S, Rosant JM, Saïd F, Salmond J, Talbaut M, Voogt J (2005) The urban boundary layer field experiment over Marseille UBL/CLU-ESCOMPTE: experimental set-up and first results. Bound Layer Meteorol 114:315-365

Monin AS, Obukhov AM (1954) Basic laws of turbulent mixing in the surface layer of the atmosphere. Tr Akad Nauk SSSR Geophiz Inst 24:163-187

Morille Y, Haeffelin M, Drobinski P, Pelon J (2007) STRAT: structure of the atmosphere from single channel lidar data. J Atmos Ocean Technol 24:761-775

Niino H (1987) The linear theory of land, and sea breeze circulation. $J$ Meteor Soc Jpn 65:901-920

Noh Y, Cheon WG, Hong SY, Raasch S (2003) Improvement of the k-profile model for the planetary boundary layer based on large eddy simulation data. Bound Layer Meteorol 107:401-427

Omrani H, Drobinski P, Dubos T (2015) Using nudging to improve global-regional dynamic consistency in limited-area climate modeling: what should we nudge? Clim Dyn 44:1627-1644

Omrani H, Drobinski P, Dubos T (2013) Optimal nudging strategies in regional climate modelling: investigation in a Big-Brother Experiment over the European and Mediterranean regions. Clim Dyn 41:2451-2470

Peixoto JP, De Almeida M, Rosen RD, Salstein DA (1982) Atmospheric moisture transport and the water balance of the Mediterranean sea. Water Resour Res 18:83-90

Puygrenier V, Lohou F, Campistron B, Saïd F, Pigeon G, Bénech B, Serca D (2005) Investigation on the fine structure of sea-breeze during ESCOMPTE experiment. Atmos Res 74:329-353

Rotunno R (1983) On the linear theory of the land, and sea breeze. J Atmos Sci 40:1999-2009

Ruti P, Somot S, Giorgi F, Dubois C, Flaounas E, Obermann A, Dell'Aquila A, Pisacane G, Harzallah A, Lombardi E, Ahrens B, Akhtar N, Alias A, Arsouze T, Raznar R, Bastin S, Bartholy J, Béranger K, Beuvier J, Bouffies-Cloche S, Brauch J, Cabos W, Calmanti S, Calvet JC, Carillo A, Conte D, Coppola E, Djurdjevic V, Drobinski P, Elizalde A, Gaertner M, Galan P, Gallardo 
C, Gualdi S, Goncalves M, Jorba O, Jorda G, Lheveder B, Lebeaupin-Brossier C, Li L, Liguori G, Lionello P, Macias-Moy D, Onol B, Rajkovic B, Ramage K, Sevault F, Sannino G, Struglia MV, Sanna A, Torma C, Vervatis V (2015) MED-CORDEX initiative for Mediterranean climate studies. Bull Am Meteorol Soc:doi. doi:10.1175/BAMS-D-14-00176.1

Salameh T, Drobinski P, Vrac M, Naveau P (2009) Statistical downscaling of near-surface wind over complex terrain in Southern France. Metetorol Atmos Phys 103:243-256

Salameh T, Drobinski P, Dubos T (2010) The effect of indiscriminate nudging time on the large and small scales in regional climate modelling: Application to the Mediterranean Basin. Q J R Meteorol Soc 136:170-182

Skamarock WC, Klemp JB, Dudhia J, Gill DO, Barker DM, Duda MG, Huang XY, Wang W, Powers JG (2008) A description of the advanced research WRF version 3. Technical Report, NCAR

Smirnova TG, Brown JM, Benjamin SG (1997) Performance of different soil model configurations in simulating ground surface temperature and surface fluxes. Mon Weather Rev 125:1870-1884
Stéfanon M, Drobinski P, D’Andrea F, Lebeaupin-Brossier C, Bastin S (2014) Soil moisture-temperature feedbacks at meso-scale during heat waves over Western Europe. Clim Dyn 42:1309-1324

Steyn DG (2003) Scaling the vertical structure of sea breezes revisited. Bound Layer Meteorol 107:177-188

Steyn DG (1998) Scaling the vertical structure of sea breezes. Bound Layer Meteorol 86:505-524

Taubnam EJ, Mlawer SJ, Brown PD, Iacono MJ, Clough SA (1997) A validated correlated k-model for the longwave. J Geophys Res 102:16663-16682

Trigo IF, Davies TD, Bigg GR (1999) Objective climatology of cyclones in the Mediterranean region. J Clim 12:1685-1696

Valcke S (2006) OASIS3 user guide (prism_2-5) CERFACS technical support. TR/CMGC/06/73, PRISM report No 3; Toulouse, France, $\mathrm{p} 60$

Walsh JE (1974) Sea-breeze theory and applications. J Atmos Sci 31:2012-2026 